Mavi Atlas, 5(2)/2017: 577-625. Araştırma Makalesi | Research Article

Makale Geliş | Received: 21.08.2017

Makale Kabul | Accepted: 03.10.2017

DOI: $10.18795 /$ gumusmaviatlas.357656

Ferdi KİREMITÇ̧i

Yrd. Doç. Dr. | Assist. Prof. Dr. Gümüşhane Üniversitesi, İlahiyat Fakültesi, İslam Tarihi ve Sanatları Bölümü, Gümüşhane-Türkiye Gümüşhane University, Faculty of Divinity, Department of Islamic History and Art, Gümüşhane-Turkey

orcid.org/0000-0002-4514-8418

ferdikiremitci@hotmail.com

\title{
Yûnus Emre’nin “Benem” Redifli Bir Gazeli Üzerine Çoğulcu Tahlil Denemesi
}

\begin{abstract}
$\ddot{O} z$
Genelde İslâm kültür ve medeniyetinin özelde ise Türk-İslâm edebiyatının meşhur isimlerinin başında Yûnus Emre gelir. Kuşkusuz ki onun bu şöhreti öncelikle dinî-tasavvufî birikimini her kesimden insanın gönlünü fethedecek bir samimiyetle anlatabilmesinden, daha sonra da sözlerini coşkun bir lirizm ve arı bir Türkçeyle söyleyebilmesinden kaynaklanır. Bundan dolayı onun şiirleri, hem yaşadığı dönemde hem de sonraki asırlarda pek çok kișiyi derinden etkilemiş; bu şiirleri okuyanlar Yûnus Emre'nin duygu ve düşünce dünyasıyla hemhâl olmak için ciddi çabalar sarf etmişlerdir. Bu çalışma, Yûnus Emre Dîvânı'nda yer alan "benem” redifli bir gazelin çoğulcu yaklaşımla tahliline yöneliktir. Çalışma iki ana bölümden oluşmaktadır. Birinci bölümde, dinî-edebî metinleri incelerken kullanılan klâsik ve modern yöntemlerin birbirleriyle olan ilişkisinden ve çoğulcu yaklaşımın bu yöntemler arasındaki yerinden bahsedilmiştir. İkinci bölüm, ilgili gazelin "toplumu, şairi, okuru ve metni” öne çıkaran yöntemlerden yararlanarak ve bunların bir sentezini oluşturarak yapılan incelemesini içermektedir. Bu çalışmayla ilim ve irfan geleneğimizin köşe taşlarından biri olan Yûnus Emre'yi, yine onun bir şiiriyle daha iyi anlamak amaçlanmış; bu amaca ulaşmak için de klâsik ve modern tahlil yöntemlerinin verilerinden hareket edilmiştir.
\end{abstract}

Anahtar Kelimeler: Yûnus Emre, Çoğulcu Tahlil, Dinî-Tasavvufî Şiir, Metin Şerhi, Gazel.

\section{The Multiplear Analysis Essay on the a Gazel of "Benem" Repeated Word of Yûnus Emre}

\begin{abstract}
Yûnus Emre is in general one of the most famous names of Islamic culture and civilization, especially TurkishIslamic literature. Certainly, his reputation primarily is due to the fact that he can tell his own religious-mystical accumulation with a sincerity to win the hearts of every peoples and then he can say his words with luscious lyricism and a simple Turkish. Hence, his poems have deeply influenced many people both during his lifetime and in the following centuries and those who read these poems have made serious efforts to be together with the world of emotions and thoughts of Yûnus Emre. This study is based on the analysis by a pluralistic approach of the gazel of "benem" repeated word in Dîvân of Yûnus Emre. The study consists of two main parts. In the first chapter, the relation between classical and modern methods used in the study of religious-literary texts and the place of the pluralist approach between these methods are mentioned. The second section contains the examination of the relevant gazel by making use of methods that emphasize "society, poetry, lecture and text" and by making a synthesis of them. This work aims to better understand the Yûnus Emre who is one of the cornerstones of our tradition of knowledge and wisdom with his poem and to achieve this aim, it has also been moved from the data of classical and modern methods of analysis.
\end{abstract}

Keywords: Yûnus Emre, Multiplear Analysis, Religious-Sufi Poetry, Text Review, Gazel. 


\section{Giriş}

Her milletin ve her dilin bugüne kadar ortaya koyduğu şiirler arasında sayısı az olan kimi şiirler vardır ki bunlar kuşaktan kuşağa aktarılmış, her dönemde sevilmiş, "kalıcı" olarak nitelenebilecek sanat ürünleri olarak değerlendirilmiştir. Şüphesiz ki bu nitelikteki şiirlere sahip ilk akla gelen isimlerden birisi, belki de birincisi yüzyılların ötesinden bize seslenen, bizi bugün de derinden etkileyen Yûnus Emre'dir (Aksan 2013: 269-270).

Yûnus Emre bir Türk-İslâm mutasavvıfı olarak ayrı bir üslubun, kendine has bir tarzın temsilcisi olan bir mektep şairidir. Ahmed Yesevî ile başlayan "hikmet" geleneği, onda "ilâhî" adıyla ve daha âşıâne bir eda, üstün bir şekil ve muhteva ile tecelli etmiş; bu yönüyle o, kendisinden sonra izlenip takip edilen fakat hiçbir zaman aşılamayan bir üstat olarak temayüz etmiştir. Hiç kuşku yok ki ona bu vasfi kazandıran, görünüşte kolay ancak söylenişi hiç de öyle olmayan sehl-i mümtenî tarzındaki şiirleridir. Gönlünde dalgalanan Allah sevgisini satırlara geçiren Yûnus Emre, bu şiirlerine ilâhî bir ruh ve ahenk vermiş; onları adeta söylerken besteleyerek birer lirizm şaheseri hâline getirmiştir (Tatc1 2008b: 99-109).

Yûnus Emre gibi kültür ve medeniyet mimarlarımızı hakkıyla tanıyamamak ve sahip oldukları değerleri günümüz insanına anlatamamak, kuşkusuz ki günümüz araştırmacılarının en büyük problemidir. Aslında klâsik devirlerde, bu tür tanıtma ve açıklama çalışmaları sıkça yapılmış ve bunların çoğu diğerlerine göre anlaşılması biraz daha güç olan tasavvufî metinler üzerinde yoğunlaşmıştır. Ancak, son dönemlerde gerek klâsik yöntemlerin kullanıldığ̣, gerekse de Batılı yaklaşımların esas alındığı böylesi tasavvufî metin incelemelerinin üzerinde yeterince durulmadığı görülmektedir. $\mathrm{Bu}$ çalışma, Yûnus Emre Dîvânı'nda yer alan "ilâhî” türündeki bir gazelin “çoğulcu” bakış açısıyla tahlilini içermekte; söz konusu eksikliği bir nebze de olsa gidermeyi hedeflemektedir. 
Yûnus Emre Dîvânı'nda dokuz tane “benem” redifli gazel ${ }^{1}$ bulunmaktadır. Çalışmamızda bu gazellerin birincisi üzerinde durulacak, yeri geldikçe aynı redifteki diğer gazellerden ve şairin başkaca şiirlerinden de istifade yoluna gidilecektir. ${ }^{2}$ Ancak, metni incelemeye geçmeden önce İslâmî Türk edebiyatı alanında uygulanan klâsik ve modern tahlil yöntemlerinden, yeni yaklaşımların bu sahadaki metinlere uyarlanıp uyarlanamayacağıyla ilgili görüşlerden ve "çoğulcu" bakış açısının bu inceleme metotlarıyla olan ilişkisinden kısaca bahsetmek yerinde olacaktır:

\section{Klâsik Metinlerin Tahlilinde Yöntem Meselesi ve Çoğulcu Yaklaşım}

Klâsik metinlerin tetkik ve tahlil meselesi Ali Nihat Tarlan'ın “Metinler Şerhine Dair" adlı yazısından bugüne değin pek çok alan araştırmacısının konusu olmuştur. Esasen Tarlan'ın bu yazısında yapmış olduğu tespitler, günümüzde ortaya konan yeni yaklaşımların o yıllarda bile fark edildiğini açıkça göstermektedir (Tarlan 1981: 191204). ${ }^{3}$

\footnotetext{
${ }^{1}$ Yûnus Emre'nin şiirleri farklı nazım şekilleriyle ilişkilendirilebilmektedir. Bu konuya çalışmamızın "Nazım Şekli" başlığı altında değinilmiştir. Çalışmamızda tahlil edilen şiirden ise "gazel" nazım şekli olarak bahsedilmiștir.

${ }^{2}$ Üzerinde durulacak gazelin tahlili esnasında, Yûnus Emre'yle ilgili yeri geldikçe verilen diğer metin örneklerinde ve gazelli ilgili bazı açılamalarda Mustafa Tatcı'nın Yûnus Emre Külliyâtı I/Yûnus Emre Divânı-İnceleme ve Yûnus Emre Külliyâtı II/Yûnus Emre Divânı-Tenkitli Metin adlı kitaplarından; M. Efdal Emre'nin Yûnus Emre Dîvânı ve Serhi adlı kitabından yararlanılmıștır.

${ }^{3}$ Metin şerhi ve tahlilinin tanımı ve farklı ya da benzer yönleri konusunda Tarlan'dan sonra kaleme alınmış şu çalışmalara da bakılabilir: DİLÇîN, Cem (2003). "Cumhuriyet" in 80. Yılında Divan Şiiri Üzerine Düşünceler" Türkoloji Dergisi, 16/2: 1-21; YENiTERZİ, Emine (1999). "Metin Şerhi ile İlgili Görüşler", SÜ Türkiyat Araştırmaları Enstitüsü Türkiyat Araştırmaları Dergisi, 5: 59-68; AKAR, Metin (1994). "Metin Şerhi Meselesi", Su Kasidesi Şerhi, Ankara: TDV Yayınları; AKKUŞ, Metin (1992). "Metin Şerhi Geleneği Tarlan Mektebinden Haluk İpekten"e", Yedi İklim, 32: 67-78; MENGİ, Mine (2000). "Metin Şerhi, Tahlili ve Tenkidi Üzerine", Divan Şiiri Yazılarl, ss. 72-80, Ankara: Akçăg Yayınları; MENGİ, Mine (2007). "Metin İncelemesi Aşamaları, Terimleri ve Bunlardan Biri: Metin Tahlili", Turkish Studies, 2/3: 407-417; DOĞAN, Muhammed Nur (2002). "Metin Şerhi Üzerine”, Eski Şiirin Bahçesinde, ss. 11-25, İstanbul: Ötüken Yayınları; PEKOLCAY, Necla (1992). "Metin Şerhi Hakkında", I. Eski Türk Edebiyatı Kollogyumu, 17-18 Ocak, Ankara: İlesam Yayınları; OKAY, Orhan (1990). "Eski Şiirimize Yaklaşmak", Sanat ve Edebiyat Yazıları, ss. 82-87, İstanbul: Ötüken Yayınları; CANIM, Rıdvan (1996). "Metin Şerhi Geleneğimiz Çerçevesinde Tarlan ve İpekten'in Kaleminden Fuzuli'nin 'Sana' Redifli Gazeli”, Fuzuli Kitabl: 500. Yllında Fuzuli Sempozyumu Bildiriler, (Haz. Beşir Ayvazoğlu). ss. 129-140, İstanbul: Büyük Şehir Belediyesi Kültür İşleri Dairesi Başkanlı̆̆ 1 Yayınları; KORTANTAMER, Tunca (1994). "Teori Zemininde Metin Şerhi Meselesi”, EÜEF Türk Dili ve Edebiyatı Araştırmaları Dergisi, 8: 1-10; SARAÇ, Yekta (1999). "Divan Tahlilleri Üzerine", İlmi Araştırmalar Dil, Edebiyat, Tarih Incelemeleri, 8: 209-219.
} 
Tarlan, metin tetkik ve tahlilini şerhin alt basamağı olarak görmüştür. Onun klâsik metinlerin anlaşılması hususunda farklı yöntemlerden yararlanılması gerektiğiyle ilgili görüşleri yeni yaklaşımlarla örtüşecek şekilde şöylece özetlenebilir: 1. Metnin kendisini incelemek gerekir: Yapısalcı kuram. 2. Şairin bilinçaltında olan ve farkında olmadan yazdıklarını anlamak gerekir: Psikanalitik kuram. 3. Şairin zihin ve his dünyasının işleyişini kavramak gerekir: Psikolojik kuram. 4. Farklı şekillerde metinleri inceleyerek ortak ve farklı özelliklerini tespit etmek gerekir: Yapısalcı kuram (Güleç 2010: 87-88).

Tarlan'ın söylemek istediği aslında, şiir dilinin çok değişik açılardan incelenebilmesi ve bu dilin niteliklerinin de bu değişik açılardan bakılınca daha belirgin bir biçimde ortaya çıkabilecek olmasıdır (Aksan 2013: 27). Ne var ki klâsik şiir dilinin çözümlenmesinde farklı yöntemlerin bir işe yaramayacağını savunanlar da vardır. Metin şerhi ve tahlili konusundaki bu görüş ayrılıklarını temelde üç başlık altında toplamak mümkündür: 1. Klâsik metin şerhi metodunda 1srar edenler: Metin Akkuş, Atilla Şentürk, Muhammet Nur Doğan, Metin Akar, Rıdvan Canım, Emine Yeniterzi gibi. 2. Klâsik metin şerhi metodunu da ihmal etmeden yeni metotlara sıcak bakanlar: Orhan Okay, Tunca Kortantamer, Mine Mengi gibi. 3. Klâsik metinlerin yeni metotlara göre tekrar ele alınması gerektiğini söyleyenler: Cem Dilçin, Yavuz Bayram, İlhan Genç, Dursun Ali Tökel gibi (Güleç 2010: 89-108).

Bu cümleden olmak üzere klâsik metin şerhi metodunda ısrar edenlerin başında gelen Metin Akkuş, klâsik metinleri sadece Batı menşeli teorilerle tahlil etmenin yanlışlığıyla ilgili olarak şunları söylemektedir (Akkuş 1992: 67-78):

Metin tahlili olarak adlandırdığımız çağdaş metin incelemelerindeki estetik anlayış çoğu zaman Batı estetiği veya edebiyat teorisinin etkisi altındadır. Buna karşılık klâsik edebiyatın güzellik-değerlilik anlayışı doğu kültürüne has bir estetik anlayışa veya edebiyat teorisine dayanmaktadır. Bu nedenle yine metin tahlili anlamındaki metin şerhi edebiyat teorisi ve edebiyat tarihi birikimiyle birlikte klâsik edebiyatın kaynaklarını da bir bilgi dağarcığı olarak hazırlamış olmayı gerektirir.

Benzer görüşe sahip olan Atilla Şentürk, asıl problemin klâsik tahlil yöntemlerinin yetersizliğinden ziyade değişen dünya algısından ve günümüz insanının 
geçmişe olan kültürel yabancılaşmasından kaynaklandığını düşünmekte ve konuyla ilgili görüşlerini şu cümlelerle özetlemektedir (Özer 2005: 50-51):

Batılı ve modern kuramlarla eski metinlere yaklaşmaya çalışmak, zaten anlaşılmasında zorluk çekilen bu metinleri iyice içinden çıkılmaz hâle getirmekten başka bir işe yaramaz. (...) Zaten oldukça zor ve girift olan bu konuları ilgisiz bir takım kuramlarla içinden çıkılmaz ve hiç anlaşılmaz hâle getirmeyi doğru bulmuyorum.

Ancak klâsik metinlerin yeni metotlara göre tekrar ele alınması gerektiğini savunan Cem Dilçin, klâsik şiirdeki güzelliğe ve yazınsal değerlere ulaşabilmek için “deyişbilim (stylistic), metin dilbilimi (text linguistics), göstergebilim (semiology), yapısalcılık (structuralism), çeviribilim (science of translation) ve karşılaştırmalı edebiyat bilimi" gibi farklı yöntemlerden yararlanmayı ve bu uygulamanın da yaygınlaştırılmasını lüzumlu görmekte; klâsik şiirin sanat ve tekniğinin yeni yaklaşımlarla tetkik edilmeye müsait olduğunu belirtmektedir (Dilçin 2003: 1-21):

Divan şairlerinin vezni kullanışı imale ve medlerin ses sanatı olarak işlevi, ahenk öğeleri, kafiye seçimi, rediflerin çağrışım öğesi olarak ele alınışı, beyitleri oluşturan paralel ve simetrik söz yapıları, söyleyiş kalıpları, kısa ve eksiltili anlatımlar, ortak ve benzer anlatım biçimleri, türlü tekrarlar ve bunların anlama kattığı değerler, sözü tersiyle anlatma ve karşitlamalar, söz ve anlam sanatlarının birbirini destekleyici biçimde kullanımı, uzak çağrışımlar (...) gibi şiir dilini oluşturan öğeler ve başka "yazınsal değerler” üzerinde durmak, onların eserlerinin sanat yönünü açık olarak ortaya koyacaktır.

Klâsik metinlerin tahlilinde, eski yöntemleri ihmal etmeden yeni metotlardan da yararlanmak gerektiğini düşünenlerin başında Tunca Kortantamer yer alır. Ona göre, ideal tahlil modelinin ortaya çıkmasında klâsik metin şerhlerinin büyük rolü bulunmaktadır. Klâsik metotla modern yöntemlerin birbirini tamamladığını düşünen Kortantamer, bu görüşünü detaylandırmadan önce klâsik şerhleri şu cümlelerle özetlemiştir:

$\mathrm{Bu}$ tip şerhlerde öncelikle metin verilir. Sonra kelimeler ve kavramlar çok zaman dil bilgisi ağırlıklı olarak, şerhine göre, uzun veya kısa bir şekilde açıklanır. Onlarda saklı olan anlam dünyası ortaya çıkarılmaya çalışılır. Daha önce bu konuda ileri sürülmüş fikirler varsa, onlar zikredilir, tercihte bulunulur. Telmihler dünyâsı açıklanır. (...) Aslında klâsik metin şerhinin ulaştığı ustalığın tam bir planını sık sık Kur’ân tefsîrleri arasında bulmak mümkündür. 
Batılı tahlil yöntemlerini problemleriyle birlikte görmemizi ve bunların zaaflarını daima göz önünde bulundurmamız gerektiğini söyleyen Kortantamer; belli bir metot dâhilinde yapılan her türden şerhin ortak tecrübelere kazandıracağı şeyler olduğunu vurgulamakta, ne modern bir yönteme ne de klâsik yönteme çakılı kalmanın doğru olmadığını belirtmektedir. Kortantamer, temel işlevi aynı olmakla birlikte zamanla gelişen bir takım yeni yöntemlerin kullanılabileceğini ifade etmekte, bu yüzden de klâsik metinlerin hem geleneksel hem de modern yöntemlerle incelenmesi gerektiğini dile getirmektedir (Kortantamer 1994: 1-10).

Başta ontolojik analiz ve yapısalcı yaklaşım olmak üzere yeni ve farklı bakış açılarını klâsik metinlerin çözümünde kullanan ve bu şekilde pek çok uygulamalı çalışma yapan Yavuz Bayram da Batı kökenli yeni yöntemlerin altı yüzyıllık Osmanlı kültürünün ürünleri olan şiirsel metinleri anlama ve çözümlemede zaman zaman yetersiz kaldığını, bundan dolayı da bu yaklaşımları edebî metinleri tahlil bakımından tek geçerli yol olarak algılamanın fazlasıyla iddialı ve riskli olacağını belirtmiş; klâsik yöntemlerle yeni yaklaşımların harmanlanması gerektiğini şu şekilde dile getirmiştir (Bayram 2016: 290-291):

Böyle bir yaklaşım nasıl bir ifrat örneği oluşturacaksa yeni ve farklı yöntemleri bütünüyle reddetmek de bir yönüyle tefrit örneği oluşturacaktır. Zira üzerinden yüzlerce yıl geçmiş bir edebî metni (gazeli), yazıldığı dönemin sosyal ve kültürel ortamından soyutlayarak çözümlemeye ve anlamlandırmaya çalışmak kadar aynı metni aradan geçen yüzlerce yılı ve değişen sosyal ve kültürel şartlerı dikkate almaksızın modern çağın insanının algı ve anlayışına sunmak da yanlıştır. Çünkü yazıldığı dönemin sosyal ve kültürel şartları yanında çözümlenmeye çalışıldığı dönemin sosyal ve kültürel şartlarının da edebî metni anlama ve anlamlandırma çabalarını doğrudan etkilemesi kaçınılmazdır.

O hâlde edebî metinlerin çözümlenmesi, incelenmesi ve değerlendirilmesinde mutlak manada bir yöntemden söz etmek doğru değildir (Aktaş 2009: 27). Önemli olan, herhangi bir edebî eserin bütünlüğü içinde ama o bütünü oluşturan her türlü unsurun en ince ayrıntısına varıncaya kadar belli bir metoda bağlı kalınarak ele alınıp incelenmesi, değerlendirilmesi ve yorumlanmasıdır (Çetişli 2014: 346). Bu, edebiyatın gaye ve mahiyetine en uygun olan tarzdır. Zira edebî eser, ancak kendi içinde organik bir bütün hâline geldiği zaman, güzellik ve mükemmeliyete ulaşır (Kaplan 1979: 7-8). Bu 
mükemmeliyeti keşfetmek ise metnin iç ve dış ögelerini aynı oranda önemsemekle mümkündür. Yani, şiir tahlillerinde "şairin şiirle topluma anlattıkları, şairin şiiri yazdığı andaki ruhsal durumu, düşünsel eğilimi ve varsa etkilendiği felsefelerle diğer sanatlara olan yakınlığı" gibi dışsal unsurların yanında "ritim, ölçü, ses uyumu, anlatının kurmaca olarak yapısı, imge düzeni” gibi içsel unsurlar da dikkate alınmalıdır. Zaten bu dışsal ve içsel özellikler birbiriyle kopmaz bağlar içinde olup şiirin fiziğini ve kimyasını oluşturmaktadır (Cengiz 2006: 53).

Aslında "Edebiyat eserinin eleştirisi nasıl bir metot, yöntem veya tavır içinde yapılmalıdır?" sorusuna, Platon'dan günümüze uzanan süreçte herkesin hem-fikir olduğu bir cevap verilememiştir. Nitekim tenkit tarihine baktığımızda konuyla alakalı pek çok farklı anlayış ve metotla karşı karşıya kalırız ve bu tenkit metotlarının temelde dört ana grup altında toplandığını görürüz: "Dış dünyaya ve topluma dönük eleștiri”, "sanatkâra dönük eleştiri”, "okuyucuya dönük eleştiri” ve "esere dönük eleştiri” (Çetişli 2014: 329-330). Bunlardan birincisi, sanatı sanat yapan özellikleri, eserin dış dünya ile olan ilişkilerinde bulur ve sanat eserini insanı, hayatı, toplumu yansıtan bir aynaya benzetir (yansıtma kuramları gibi). İkincisi, sanatın sırrını sanatçıda arayanlardır. Bunlara göre sanat duyguların anlatımıdır (anlatımcılık kuramları gibi). Üçüncüsü, dış dünyayı ve sanatçıyı değil de okuru ön plana alanlar tarafından takip edilen metottur. Bu görüşte sanatın özü, okurda uyandırdığı estetik zevk ve düşüncede aranır (duygusal etki kuramı ve alımlama estetiği gibi). Sonuncusu ise sanatın özünü eserin başka şeylerle ilişkisinde değil de doğrudan doğruya eserin kendisinde arayanların tarzıdır. Bunlara göre sanat eserini diğer yapıtlardan ayıran özellik, sanat eserlerine özgü bir yapıdır (biçimci ve yapısalcı kuramlar gibi) (Moran 2005: 10).

Edebî metin tahlillerinde bu yaklaşımlardan sadece birini esas almak çoğu kez bizi yanıltabilecektir. Çünkü edebiyat eserlerinin sadece yapısını dikkate almak ve hayat değerlerine gözümüzü kapamak kısır bir yöntemle yetinmek olur. Aynı şekilde metnin sadece yan etkilerine önem verenler de eserin yapısı üzerinde biçimciler kadar titizlikle durmadıkça sanat eserinin hakkını vermekte yetersiz kalacaktır (Moran 2005: 333). 
$\mathrm{Bu}$ durum, edebî metinlerin çoğulcu bir bakış açısıyla değerlendirilmesini gerekli kılar. Şüphesiz ki edebî metinlerin birincil kaynağı bizatihi metnin kendisidir. Ancak, bunun yanısıra inceleyiciyi güçlendiren, incelemesine destek olan ikincil kaynaklar da vardır. Bunlar, yazarın diğer eserleri, yazarın biyografisi, eserin yazıldığ 1 dönemle ilgili tarih ve sosyoloji gibi alanlarda yazılmış kitaplar, psikoloji, linguistik, mitoloji, din gibi alanlarla ilgili bilgiler ya da dünya edebiyatından başka edebî eserler olabilmektedir. İşte "çoğulcu" inceleme bu birincil ve ikincil kaynakları birlikte değerlendirmenin diğer bir ifadesidir. Bu inceleme, araştırmacıya bir anlatım rahatlı̆̆ sağlayan, onu bir tek yöntem içinde bunalıp kalmaktan kurtaran eklektik bir yöntemdir. $\mathrm{Bu}$ yöntemde inceleyici, bir edebî eseri kendi sezgi gücüne dayanarak, metnin ağır basan özelliğine göre ve bu özelliğe uygun düşen bir veya birkaç metottan istifadeyle değerlendirebilmektedir (Aytaç 2013: 109-113).

Çoğulcu yaklaşımda, metin tahlilcisi gerçekten amacına ulaşabilmek için şu sorulara cevap bulmak durumundadır:

1. Edebî metin, yazıldığı dönemin siyasî, sosyal, ekonomik, askerî vb. alanlarından izler taşıyor mu? Taşıyorsa bunlar metnin teşekkülüne ne ölçüde tesir etmiştir? Sanatkâr, toplumun daha çok hangi dinamiklerinden beslenmiştir? Sanatkârın tesiri altında kaldığı kişi ya da kişiler var mıdır? Edebî metnin dış dünyaya ve topluma etkisi olmuş mudur? Olmuşsa toplum bireyleri ya da diğer sanatkârlar bundan ne kadar etkilenmişlerdir?

2. Sanatkâr sahip olduğu ruh hâlini, edebî ve estetik algısını, dünya görüşünü ve varsa etkilendiği felsefe ya da felsefeleri esere yansıtmış mıdır? Edebî metinde, sanatkâra ait başkaca kaynaklarda yer almayan biyografik bilgiler var mıdır? Metinsanatkâr ilişkisi metinde açıkça gözükmekte midir yoksa bu sezdirilmekte midir?

3. Metin okuyucuya yorum imkânı sunmakta mıdır? Metinde çağrışım değeri kuvvetli ögeler bulunmakta mıdır? Varsa metni anlam zenginliğine sahip k1lan bu unsurlar nelerdir? Okuyucunun metni yorumlayışı zevk ve duygu merkezli midir yoksa düşünsel midir?

4. Sanatkâr eserinde hangi konu ve tema üzerinde durmaktadır? Metnin konusu hangi yap1 sınırları içinde işlenmektedir? Metnin iç yapısı, hangi alt birimlerden oluşmakta ve bunlardan meydana gelen bütün nasıl inşa edilmiştir? Metnin türüne uygun olarak hangi estetik unsurlardan yararlanılmıştır? Metnin dili nasıl bir hassasiyetin ürünüdür? Metindeki kelime kadrosunun kaynağ 1 nedir? Eserin bütününe hâkim olan üslubun mahiyeti ve nitelikleri nelerdir? 


\section{Yûnus Emre’nin “Benem” Redifli Gazelinin Tahlili}

Edebiyat tarihimizde kendine özgü bir mana ve aşk dili kuran Yûnus Emre, Dîvân'ındaki bazı manzumelerinde, sade olmakla birlikte derin manalar yüklü mecazî/metaforik bir dil kullanmıştır. Esasen onun şiirlerinde yoğun bir sembolizm yoktur. Fakat zaman zaman bir şirinde veya bir şiirinin bazı beyit ve kıtalarında bu tür tercihlerde bulunmuş, seçtiği motiflerin sembolik değerlerini de çoğu kez "insan ve tasavvuf" çerçevesinde şekillendirmiştir. Hiç kuşku yok ki Yûnus Emre gibi sûfî şairlerin kullandıkları dil, anlaşılır gibi olsa da, insanların akıl ve gönül bilgisi farklı seviyede olmasından dolayı gittikçe derinleşmiş ve bu sebepten izaha muhtaç hâle gelmiştir (Tatc1 2008c: 4-6).

Türk edebiyatında izah ve şerh geleneği oldukça eskiye dayanmaktadır ve bu geleneğin bir parçası olarak Yûnus Emre'ye ait bazı manzumelerin farklı zaman dilimlerinde çeşitli şerhlere tabi tutulduğu görülmektedir. ${ }^{4}$

İşte bu çalışma da, böylesi bir çabanın mahsulü olup Yûnus Emre Dîvânı'nda yer alan "177, 185, 187, 193, 194, 195, 199, 211, 212" numaralı "benem" redifli gazellerden birincisini çoğulcu yaklaşımın imkânlarıyla daha iyi okuyabilmek için ortaya konmuştur. Dîvândaki bu gazeller şekil ve muhteva bakımından birbirine oldukça benzemekte, hatta konu ve tema bakımından neredeyse birbirinin tekrarı mahiyetindedir.

\footnotetext{
${ }^{4}$ Örneğin Şehzâde, Niyâzî-i Mısrî, İsmâil Hakkı Bursevî ve Şeyh Ali Nakşbendî, Yûnus Emre'nin "Çıkdım erik dalına anda yedim üzümü/Bostan ıssı geldi eydür ugurladım kozumu" matla'lı şathiyesine şerh yazmışlardır. Ayrıca İsmâil Hakkı Bursevî, şairin "Strâtdan gel sıfâta anda safâ bulasın/Hayâllere talma kim dôsta mahrem olası" matla'lı gazeli ile "Adım adım ileri beş âlemden içeri/On sekiz bin hicâbı geçdim bir dăg içinde" matla'lı ilâhîsini de şerh etmiştir (Ceylan 2007; Çelebioğlu, 1998; Pekolcay ve Sevim 1991; Tatcı 1988). Yine, Yûnus'a ait bazı manzumelerin Batılı inceleme yöntemleriyle ele alındığı da vâkidir. Örneğin şairin "Çıkdım erik dalına anda yedim üzümü/Bostan ıssı geldi eydür ugurladım kozumu" beyitiyle başlayan manzumesini İsmail Yakıt "sembolizm" açısından (Yakıt 2002). Hilmi Yavuz "yapısalcılık" açısından (Yavuz 2005: 73-76) ve A. İhsan Kolcu ise "hermenötik" açıdan (Kolcu 2011: 393-403) değerlendirmeye tabi tutmuştur. Hülya Çevirme ise şairin "Taşstı yine deli gönül/Sular gibi çağlar mısın/Aktın yine kanlı yaşım/Yollarımı baglar mısın" dörtlüğüyle başlayan manzumesini "gösterge bilim" açısından incelemeye çalı̧̧mıştır (Çevirme 2001: 75-80).
} 


\section{A. Gazelin Metni}

1. Haber eylen 'âşılara '1şka gönül viren benem 'Işka bahâ kim yitüre "1şk ma'denin bulan benem

2. Yir gök tolu bu '1şk durur '1şksuz hîç nesne yok durur 'Işk bahrisi olubanı denizlere talan benem

3. Deniz yüzinden su alup sunı virürem göklere Bulutlayın seyrân idüp 'Arş'a yakın varan benem

4. Yıldırım olup şakıyan gökde melâik tokıyan Bulutlara hüküm sürüp yagmur olup yagan benem

5. Gördüm gögün meleklerin her biri bir cünbişdedir Hak Çalab'un zikrin ider İncîl ü hem Kur'ân benem

6. Gördüm diyen degül gören bildüm diyen degül bilen Bilen oldur gösteren ol '1şka esîr olan benem

7. Sekiz uçmak 'âşıklara köşk ü sarâydur anlara Mûsî'leyin hayrân olup Tûr Tagı'nda kalan benem

8. Kalem çalınıcak görgil haber böyle durur bilgil Kâlû belâ kelecisin bunda haber viren benem

9. Delü oldum adum Yûnus 'işk oldu bana kulavuz Hazret'e degin yalunuz yüz süriye varan benem

\section{B. Gazelin Tahlili}

Şüphesiz ki klâsik veya Batılı her tahlil yönteminin kendine has kriterleri ve uygulama biçimleri bulunmaktadır. Çoğulcu yaklaşımda istenen, ya metne en uygun olan tahlil yöntemini tespit ederek incelemeyi bu yöntemin kurallarına göre ayrıntılı olarak yapmak ya da metne birkaç tahlil yönteminin genel çerçevesinden hareketle farklı açılardan bakmaktır.

Bu çalışmada, ikinci yoldan gidilerek Yûnus Emre'nin ilgili gazeli “dış dünyaya ve topluma dönük eleştiri”, "sanatkâra dönük eleştiri”, “okuyucuya dönük eleştiri” ve "esere dönük eleştiri” olmak üzere dört ana başlık altında değerlendirilecektir. Bu değerlendirmeler yapılırken dinî-tasavvufî şiir geleneğinin hassasiyetleri dikkate alınacak, yeri geldikçe de modern bakış açılarının yöntemlerinden yararlanılacaktır.

\section{Dış Dünyaya ve Topluma Dönük Eleştiri/Metin-Zihniyet İlişkisi}

Daha önce belirtildiği gibi, herhangi bir edebî metni anlayabilmenin yöntemlerinden biri de, o metne toplumun bir aynası olarak bakmaktır. Çünkü her edebî 
eser, ortaya çıktığg zaman dilimine ait özelliklerden yararlanır ve dönemini farklı bakımlardan temsil eder. Döneme hâkim zevk ve anlayış, eserin yapı, tema ve anlatımında kendini hissettirir. Öyleyse bu zevk ve anlayışı metindeki hâliyle anlamak, eseri daha yakından tanımaya ve değerlendirmeye hizmet eder. En geniş anlamda "kültür değerlerini, yaşama tarzını, insanlararası ilişkileri düzenleyen güç ve kuralları" kapsayan ve "ideoloji” ya da daha doğru bir tabirle "zihniyet" olarak adlandırılabilecek bu husus, metnin yazıldığı veya söylendiği anda mevcut ve hâkim olan güçlerin birlikte oluşturduğu fakat bunların hepsinden farklı bir zevk ve anlayışı ifade etmektedir (Aktaş 2009: 29).

Yukarıdaki gazelin zihniyeti hakkında konuşmak için metinde yer alan bazı kelime ve kelime grupları üzerinde durmak ve bunların metinde kazandıkları değerlerle ilgili bilgi sahibi olmak gerekmektedir. Metnin zihniyetini gösteren başlıca söz varlıkları sırasıyla şunlardır: “"âşıklar”, “"1şka gönül viren”, “"1şka bahâ kim yitüre, “"1şk ma“deni”, ““1şkssuz hîç nesne yok durur”, “1şk bahrisi”, “"1şk oldu bana kulavuz”, "bilen oldur gösteren”, “ol "1şka esîr olan”, "hayrân olup”, "kâlû belâ", "delü oldum”, “gördüm diyen degül gören”, "bildüm diyen degül bilen”, "Hazret'e degin yalunuz yüz süriye varan".

Görüldüğü gibi bu kelimelere sadece niceliksel olarak bakıldığı zaman bile şairin temsil ettiği zihniyet hakkında bir tahminde bulunmak zor olmayacaktır. Kelimelerin en sık tekrar edileni “aşk”"tır. Ancak bu, cismanî ve nefsanî olandan uzak, manevî ve ilâhî olana yakın, birey tarafindan kazanılmamış, Allah tarafından ihsan edilmiş bir “aşk”"tır. Nitekim şair, bu aşkın “kişinin gönlünü ona feda etmesi, kıymetinin ölçülememesi, onsuz hiçbir varlığın dahi düşünülememesi, tam olarak idrak edilememesi, her tercihin ona göre yapılması, kişiyi esir alması ve kendinden geçirmesi, elest meclisinde takdir edilmesi, insanı Hazret-i Allah'a ulaştırması" gibi özelliklerinden bahsetmiş; böylece tarif ettiği aşkın “tasavvuf"un getirdiği dikkat ve duyarlılıkla yorumlanması gerektiğini hissettirmiştir. Öyleyse metnin en bariz olarak yansıttığ 1 toplumsal olgu (zihniyet), gönül yoluyla ve aşk aracıllığıyla Cenâb-1 Hakk'ın varlığında 
birliğe ulaşmayı hedefleyen "tasavvuf" ve onun getirdiği İslâmî hayatı düzenleyen bir bilgi birikimidir.

Bilindiği üzere, Yûnus Emre'nin yaşadığı ve dinî-edebî mahsullerini verdiği asır, sosyal nizamın esastan bozulduğu ve sonraları Haçlı seferleri ve Moğol istilası gibi büyük hadiselerin yaşandığı, dolayısıyla sıkıntılar içinde kıvranan insanların ruhî ve manevî asayiş ve sükûna muhtaç oldukları bir dönemdir. Şüphesiz ki o dönemde bu ihtiyacı temin vaadinde bulunan ve hakikaten de bu eksikliği gideren "tasavvuf" düşüncesi olmuştur (Köprülü 2014: 285-286).

O hâlde dönemin bu siyasî ve sosyal yapısının halktan biri olan Yûnus Emre'yi ve onun sanatını etkilememesi düşünülemez. Hâl böyle olunca, onu ve şiirlerini anlamak, yaşadığı dönemdeki değişikliklerin ve dönüşümlerin dilde, şiirde, zevkte, yaşama tarzında, kısacası insanın görünüşünde nasıl etkili olduğunu bilmekle mümkündür. Bu bilginin incelemeye tabi tuttuğumuz gazele nasıl yansıdığı çalışmanın ileriki kısımlarında detaylandırılacaktır.

\section{Sanatkâra Dönük Eleştiri/Metin-Şair İlişsisi}

Sanatkâra yönelik eleştiride biyografi yönteminin önemi büyüktür. Ancak, bu biyografi, sanatçının ya da ilginç görünen herhangi bir şahsın hayatını anlatmaktan öte sanatkârın kişiliği ile eserleri arasında sıkı bir bağ olup olmadığg ilkesinden hareket eder. Bu ilke de temelde iki amaç için kullanılabilir: 1. Edebî eser(ler)i aydınlatmak için sanatkârın hayatını ve kişiliğini incelemek. 2. Sanatkârın psikolojisini ve kişiliğini aydınlatmak için edebî eser(ler)ini bir belge gibi kullanmak. Tabii ki sanatçıdan esere, eserden sanatçıya giden bu yöntemlerin her ikisini bir şahıs hakkında kullanmak da mümkündür (Moran 2005: 131-132).

İncelemeye çalıştı̆̆ımız gazelde, şairin psikolojisinin, özellikle de edebî kişiliğinin temel dinamiklerine işaret eden bazı sözlüksel göstergeler mevcuttur. Bunlar, her beyitte tekrarlanan "benem" kelimesi ile birkaç beyitte yer alan "Bulutlayın seyrân idüp 'arşa yakın varan benem, Kâlû belâ kelecisin bunda haber viren benem, Hak Çalab'un zikrin ider İncîl ü hem Kur'ân benem, Mûsîleyin hayrân olup Tûr Tagı'nda 


\section{Ferdi KİREMITTÇI 'Yûnus Emre'nin 'Benem' Redifli Bir Gazeli Üzerine Çoğulcu Tahlil}

Denemesi", Mavi Atlas, 5(2)/2017: 577-625.

kalan benem, Yıldırım olup şakıyan gökde melâik tokıyan, Bulutlara hüküm sürüp yagmur olup yagan benem" misralarıdır. Şairin kendisini bazen gökte meleklere vuran, bazen peygamberlerin vazifesini üstlenen, hatta bazen de Allah'ın icraatlarına müdahalede bulunan bir konumda göstermesi, onun tasavvufta "şatahat" kavramıyla karşılanan psikolojik ve manevî yönüyle ilgili önemli verilerdir.

"Șatahat" kavramı, mistik tecrübeye göre sûfîlerin "işaret dili” ile "seyr ü sülûk" ve "fenâfillâh" hakikatını açıkladıkları meczubâne ve sûfîyâne söyledikleri sözleri ifade etmektedir. Bu sözlerin en bariz özelliği ise "sekr", yani manevî sarhoşluk anında söylenmiş olmalarıdır (Tatcı 1997: 29). "Ene'l-Hak (Ben Hakk'ım).” ve "Bir denize daldım, nebiler sahilinde durdu." gibi cümlelerin örnek olarak gösterilebileceği bu tür sözler, ilâhî feyz ve kuvvetli tecellilerle kendilerinden geçen, coşan ve taşan velilerin irade dışı söyledikleri ve çoğu kez de şeriata aykırı gibi gözüken ifadeleridir. Bu yüzden bir kısım veliler kendilerine geldikleri zaman o sözleri söylediklerine pişman olmuşlar ve tevbe etmişlerdir (Uludağ 2005: 327-328). Bu cümleden olmak üzere, muvahhid bir şair olarak Yûnus Emre de, şiirlerinde "vahdet-i vücûd" nazariyesini halkın anlayacağ1 bir dille terennüm etmiş; müstakil olarak kaleme aldığı edebiyatımızdaki ilk "şathiye" türündeki şiirleriyle ve yukarıda belirtilen kelime veya cümleleri farklı manzumelerinde kullanarak kendi seyr ü sülûkuna dair önemli bilgiler vermiştir.

Nitekim bir muhavvid manevî yolculuğu esnasında "makâm-1 cem'ü'l-cem””i tahsil edince Allah kendi fiillerini ona giydirmektedir. Sonra bu mazhar, kabiliyeti nispetinde "makâm-1 ehadiyyet"e geçmekte ve mutlak manada tevhide ulaşmaktadır. "Fenâ ender fenâ" ve "bekâ ender bekâ"ya eren bu muvahhide Cenâb-1 Hak tüm tasarrufunu bâtından vermekte; "velâyet, sıdkıyet, kutbiyet ve nübüvvet"i bâtından giyen bu sâlik, Hak ile birleşerek arzdan göğün yedi tabakasına ve arşa kadar hükmü geçen, ölüleri dirilten bir muvahhid hâline gelmektedir (Emre 2015: 682). İlk bakışta dinin özüne aykırı gibi gözüken bu tanımlamalar, aslında sûfînin manevî terakkide son merhaleye ulaştığının bir göstergesi olarak kabul edilmektedir. İşte Yûnus Emre şiirlerinde, böylesi bir sâlik ve muvahhid olarak âlemin sultanı gibi görünür ve aslında söyleyen kişi o değil, Cenâb-1 Hakk’ in bizzat kendisidir: 
Tapduk diyem cümle dile inanmışam degme kula Yûnus dahı hod kim ola bu sözleri diyen benem (195/10)

Görüldüğü üzere Yûnus Emre, gazelindeki şathiye içerikli sözleriyle bizlere hem tasavvufî hem de edebî kişiliğiyle ilgili bu en dikkat çekici özelliğini görme imkânı tanımıştır. O hâlde, şairin bu gazelini ve dahi diğer manzumelerini onun bu yönünü dikkate alarak değerlendirmeye çalışmak, metinleri doğru anlamanın ve yorumlamanın ilk şarıı olarak karşımıza çıkmaktadır.

\section{Okuyucuya Dönük Eleştiri/Metin-Okur İlişkisi}

Okur merkezli kuramların tarihî sürecine göz gezdirildiğinde, bunların bir kısmının çok eski, bir kısmının ise yeni kuramlar olduğu görülür. Ancak, 20. yüzyılda ortaya atılmış olan iki kuram diğerlerine nazaran daha önemlidir. Bunlardan birincisi “duygusal etki kuramı”, ikincisi ise "alımlama estetiği/alımlama kuramı”dır. Bu iki kuram, okurun edebî metni neyi önceleyerek anlayacağıyla alakalıdır. Yani okur edebî metni birinci kuramın savunduğu gibi "estetik yaşantıyı" önceleyerek duygusal açıdan mı anlamaya çalışacak, yoksa ikinci kuramın önerdiği gibi "hermeneutik/yorum bilim"i önceleyerek düşünşel ve bilişsel açıdan mı anlamaya uğraşacaktır (Moran 2005: 229248)?

Şüphesiz ki bu soru tasavvufî̀ metinlerle de ilişkilendirilebilir. Böyle olduğunda ise sorunun cevabına yine bu tür eserler üzerine yapılan klâsik şerhlerde rastlamak mümkün olmaktadır. Çünkü bu şerhlerde genellikle tasavvufî tefsir yöntemi olan "keşfî te'vîl' kullanılmış; metinler tarikat intisabı sebebiyle kalben idrak edilen manevî ve sezgiye dayalı gerçeklerle, inceleyicinin zihnî-aklî becerileri doğrultusunda izah edilmiştir. O hâlde, tasavvufî metinleri incelerken başvurulabilecek en uygun okur merkezli yöntemin klâsik şerhlere de yakın olan "hermeneutik/yorum bilim" metodu olduğu söylenebilir (Tatc1 2008c: 2).

Doğuşu dinî metinler üzerine yoğunlaşan Antik Yunan'a kadar geriye giden "hermeneutik/yorum bilim", anlaşılmaz olanı veya anlaşılmamaya başlamış olanı anlaş1lır hâle getirme çabasının bir sonucu olarak ortaya çıkmıştır. Farklı düşünürlerin ileri sürdüğü “ gramatik yorumlama, psikolojik yorumlama, temel anlama, yüksek 
anlama, açımlama, önyargı-otorite, farklı anlama, sanat-gerçeklik ilişkisi” gibi değişik bakış açılarıyla gelişimini sürdüren (Toprak 2003: 23) bu yöntem, günümüzde edebî eseri "yazar-metin-okuyucu" bağlamında ele alan "göstergebilimsel kuram" gibi modern inceleme yöntemleriyle varlığını devam ettirmektedir.

Esas olarak bu yöntem, "kendini içine koyma" ve "yeniden yaşama" şeklinde özetlenmekte; metinlerin -özellikle de şiirin- anlaşılmasında temel diyalektik olarak kabul edilen, sanatkârın duygularının yeniden yaşanması ve okurun kendisini onun yerine koyması anlamına gelmektedir. Bu düşünce, edebî metinlerde, söylenen her sözün iki temel noktada değerlendirilmesi gerektiğini vurgular: 1. Her söz, onu söyleyenin düşüncelerini yansıtır. 2. Her söz, dilin bütünlüğü içerisindeki yeri ve anlamıyla da değerlendirilmelidir (Bilkan 2006: 24-25).

Bu yönüyle bakıldığında "hermeneutik/yorum bilim”, edebî metindeki gizli ya da derin anlamın ortaya çıkarılması ve yorumlanması sürecinde metnin, yazarından, yazıldığ 1 dönemden, kullanılan dilden vb. hareketle incelenmesi anlamına gelmektedir. Bir bakıma bu yöntemde, var olan farklı edebiyat kuramlarının neredeyse tamamını içine alan bir okuma ve yorumlama eyleminden söz edilmektedir (Kolcu 2011: 384).

Yûnus Emre'nin üzerinde durduğumuz gazelinin “metin-okur ilişkisi” açısından ve "hermeneutik/yorum bilim"in imkânlarıyla değerlendirilmesi, çalışmanın bundan sonraki bölümünde gerçekleştirilecektir.

\section{Esere Dönük Eleștiri/Metnin Yapı Özellikleri ve Yorumu}

Çoğulcu yaklaşımın bundan önceki üç ana başlığında, Yûnus Emre'nin ilgili gazeline "topluma/dünyaya, yazara ve okura" dönük kuramlardan hareketle bakmanın yararlı olacağı söylenmişti. Bu bölümde ise gazel, bu kuramları da dikkate alarak ama öncelikle metnin kendi yapısını öne çıkaran bir yaklaşımla değerlendirilecektir.

Bir edebî metinde -özellikle de şiirde- yapı, ses ve anlam kaynaşmasından oluşan birimlerin bir tema etrafında birleşmesiyle oluşur (Aktaş 2009: 30-31) ve genellikle de "ön yapı" ve "arka yapı" olmak üzere iki kısma ayrılır. Bu ayırımda ön yapı, "metnin dış görünümünü, şekil özelliklerini (âhenk unsurları ve nazım şekli), 
birimlerini ve şekille ilgili sanatları"; arka yapı ise, "metni oluşturan unsurların anlam alanlarını, bunların tarihsel, kültürel, dilbilgisel... bağlantılarını, metnin içeriğini (konu, tema, çağrışımlar, edebî sanatlar, metin-toplum ilişsisi, metin-şair ilişkisi...)” ihtiva etmektedir (Bayram 2016: 294).

Burada gazelin yapısını tahlil ederken yeni bir yöntem ortaya koymaktan öte, mevcut yöntemlerin sentezinden hareket edilecektir. Yani, "birimlerdeki kelimelerin anlamlarını vermek, birimlerin diliçi çevirisini yapmak, edebî sanatlardan ve genellikle de dinî-tasavvufî kelime ve terimlerden başlamak üzere klâsik edebiyatın temel kaynaklarına dair bilgilerden hareketle bu birimleri açıklamak, varsa orijinal hayal ve kurguları keşfetmek" üzerine bina edilen klâsik yöntem ile bu yöntemin aşamalarını daha organize ve ayrıntılı olarak gerçekleştirmeye çalışan yeni yaklaşımlar aynı oranda göz önünde bulundurulacaktır.

\section{a. Birinci Aşama: Gazelin Bütün Hâlinde Ön Yapısı}

\section{- Nazım Şekli}

Yûnus Emre Dîvânı'nda yer alan manzumelerin nazım şekillerinin ne olduğuyla ilgili farklı görüşler bulunmaktadır. Bu manzumelerin çoğu tür olarak tasavvuf edebiyatındaki "ilâhî" genel başlığı altında toplanan manzumelerdir ve şekil olarak daha çok "gazel” nazım şekline yakındır. ${ }^{5}$ Bilindiği üzere gazelin en belirgin teması aşktır. Dîvân şairleri, bu temayı özgün olma çabasının gereği olarak farklı hayallerle anlatmaya çalışmışlar; tasavvufî şairler ise aynı nazım şeklini çoğu kez ilâhî aşkı terennüm etmek için kullanmışlardır. Tahlil etmeye çalıştığımız gazelin bütünüyle dinî-tasavvufî hassasiyetin bir mahsulü olduğu açıktır.

\footnotetext{
${ }^{5}$ Necla Pekolcay, "çıkdım erik dalına..." ile başlayan manzumenin şerhlerinden bahsederken "Parçanın kafiye düzeni gazelinkine uygundur. Bundan dolayl, bunu Yûnus'un gazeli olarak zikreden yazmalar var. Fakat, bu, genelde ilk yedi beytinin şerhini yapanların kullandiğı ifadedir. Devamını şerh edenler ekseriyetle 'kasîde' demektedirler." tespitinde bulunmuştur (Pekolcay ve Sevim, 1991: 20). Ayn1 manzume(ler) için Ömür Ceylan ise "Dîvân şiiri tarzında fakat ilâhî muhtevasına sahip bu manzumelerin Dîvân şiirinin en işlek nazım şekli olması hasebiyle ilâhînin mukabili kabûl edilebilecek olan gazel formunda değerlendirilmesini mümkün kllmaktadır." demiş ve gazelin kasideye göre çok daha çeşitli konularda yazılabileceğini söyleyerek, "gazel-ilâhî" yakınlığından hareketle bu manzumeler için "gazel" tabirini kullanmanın daha doğru olacağını savunmuștur (Ceylan 2007: 55). Bu çalışmada ikinci görüşe tabi olunarak Yûnus Emre'nin üzerinde durulan manzumesinden "gazel" nazım şekli olarak bahsedilmiştir.
} 
Yûnus Emre'nin bu gazelinde dokuz beyit bulunmaktadır. $\mathrm{Bu}$ beyitlerin birbiriyle olan şekilsel irtibatı, ilgili nazım şeklinin genel özelliğine uygun olarak "aa, ba, ca ..." biçimindeki kafiye düzeniyle sağlanmıştır. Gazelin 1, 3 ve 9. beyitlerinde mısra ortası iç kâfiye yer aldığından bu birimlerde, "musammat gazel" hususiyeti de göze çarpmaktadır. Şair klâsik şiirlerdeki mahlas kullanma geleneğine tabi olarak, çoğu gazelinde olduğu gibi bu gazelinin son beytinde "Yûnus" mahlasına yer vermiştir.

\section{- Âhenk Unsurları/Ses Tabakası}

Vezin: İlgili gazelde aruz vezninin recez bahrindeki "müstef" ilâtün müstef 'ilâtün müstef'ilâtün müstef ilâtün" kalıbından yararlanılmıştır. Yûnus Emre'nin bu kalıbı tercih etmesinin temelde iki sebebinden bahsedilebilir. Birincisi, şair Dîvân'ının bazı manzumelerinde 8+8: 16'lı hece ölçüsünü kullanmıştır. Bu ölçüyle ilgili aruz kalıbının hece sayısı bakımından benzerlik göstermesi şaire bir ifade kolaylığı sağlamıştır. İkincisi ise, ortasından iki eşit parçaya bölünebilen bu aruz kalıbı manzumeyi musammat gazele dönüştürme imkânı sunmuş, böylece gazelin âhenk yönünü daha da kuvvetlendirmiştir.

Kafiye ve Redif: Yûnus Emre gazelin asıl kafiyesini (kâfiye-i asliyye), beşinci beyit hariç olmak üzere diğer beyitlerin ikinci mısraında yer alan Türkçe "-an” sıfat-fiil ekinin tekrarıyla oluşturmuştur (kâfiye-i şâygân). Şair, mısraların tam ortasına tekabül eden kelime sonlarında bazı ses tekrarlarına da yer vermiştir (zû-kâfiyeteyn). Birinci beyitteki “âşıklara-yitüre”, üçüncü beyitteki "alup-salup” ve dokuzuncu beyitteki "Yûnus- yalunuz" kelimeleri bu kullanımın örnekleridir. Ayrıca, şairin asıl kafiye ve redifi oluşturan ses değerlerine benzer sesleri beytin farklı yerlerinde kullanarak kafiye ve redifin oluşturduğu ritmi desteklemeye çalıştığ “eylen”, üçüncü beyitteki "virürem-seyrân”, dördüncü beyitteki "tokıyan-şakıyandiyen", altıncı beyitteki "bilen-olan-gösteren" ve yedinci beyitteki "hayrân" kelimelerindeki sesler gibi.

Türk ve İran edebiyatlarında "redif", Arap edebiyatından farklı olarak revî harfinden sonraki ayrı bir kelimeyle yapılan tekrarlardır (Dilçin 2000: 70). Yûnus Emre 
gazelin redifini, "kâfiye-i şâygân"dan sonraki ayrı bir tek Türkçe kelime olan "benem" sözcügüyle oluşturmuştur. Şairin bu kelimeyi tercih etmesi, kuşkusuz ki şiirin konusu ve mesajıyla da yakından ilişkilidir.

Kelime ve Ses Tekrarları: Klâsik şiirde, bir ibaredeki bazı kelime ve seslerin tekrarlanmasına dayalı sanatlar da vardır. Bu sanatlar, metnin sahibinin belli aralıklarla döndüğü ruh hâlini göstermesi yanında, tekrarlanan sesler vasıtasıyla sözün âhenkli olmasını, yani metnin ses yönüne katkı sunarak bir ritim oluşmasını da sağlar (Saraç 2011: 196). Yûnus Emre birinci beyitte “"1şk” kelimesini, ikinci beyitte “"1şk, durur” kelimelerini, altıncı beyitte "gör-, diyen, degül, bilen" kelimelerini, dokuzuncu beyitte ise "ol-" kelimesini tekrarlayarak gazelin ses ve anlam tabakasını kuvvetlendirmiştir. Buna ilave olarak, gazelin altıncı beytindeki "-düm” eklerinin, yedinci beytindeki "lara" eklerinin, sekizinci beytindeki “-gil”" ekinin ve dokuzuncu beytindeki "-um” ekinin yinelenmesiyle oluşan ses tekrarları da gazelin âhengini güçlendiren unsurlar arasında sayılabilir.

\section{b. İkinci Aşama: Gazelin Beyitler Hâlinde Arka Yapısı}

\section{- Birinci Beyit}

Haber eylen 'âşılklara 'ışka gönül viren benem 'Işka bahâ kim yitüre 'sşk ma'denin bulan benem

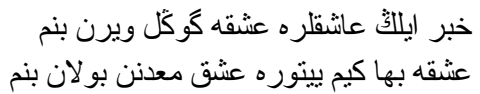

Kelime Bilgisi (Söz Tabakası): 1. haber ey-(le-n) [A.is.+T.y.f.]: Haber ulaştırmak; bilgi vermek. 2. âşık-(lar+a) [A.is.]: Aşırı seven kimse. (tsvf.) Her türlü dünya gailesi ve dünya nimeti sevgisinden uzaklaşmış, bütün sevgisini Allah'a adamış derviş. 3. '1şk-(a) [A.is.]: Bir şeye karşı aşırı düşkünlük. (tasvf.) Allah sevgisi. 4. gönül ver-(en) [T.b.f.]: İçten severek bağlanmak; âşık olmak. 5. ben-(em) [T.zm.]: Türkçe teklik birinci şahıs zamiri. 6. bahâ yitür-(e) [F.is.+T.y.f.]: Kıymet vermek, değerini belirlemek. 7. kim [T.zm.]: İnsanlar için kullanılan soru zamiri. 8. '1şk [A.is.]: Bir şeye karş1 aşırı düşkünlük. (tasvf.) Allah sevgisi. 9. ma'den-(i-n) [A.is.]: Ekonomik değer taşıyan mineral veya fosil; çok değerli ve zengin şeyleri kapsayan yer. 10. bul-(an) [T.sf.]: Arama sonucunda aranan şeyi elde etmek. 
Çeviri (Anlatı Tabakası): 1. Beytin düzyazıya çevrilişi: Âşıklara haber verin. Aşka gönül veren benim. Aşkın kıymetini kim belirleyebilir? Aşk madenini bulan benim. 2. Beytin diliçi çevirisi: (Ey insanlar!) (Bütün) âşıklara haber verin (ki) aşka severek bağlanan (kişi) (yalnızca) benim. Aşkın kıymetini (benden başka) kim belirleyebilir? Aşk madenini(n yerini) bulan kişi (de) (sadece) benim.

Dil ve Anlatım (Üslup Tabakası): Beyitteki kelimelerin sekiz tanesi Türkçe (eylen, gönül, viren, benem, kim, yitüre, bulan benem), altı tanesi Arapça (haber, 'âşıklara, '1şka, '1şka,' 'ş̧k, ma'denin), bir tanesi de Farsça (bahâ) kelimelerdir. Kelime tercihinin Türkçe ağırlıklı olması, beytin açık ve anlaşılır bir dille yazıldığının en bariz göstergesidir. Beyit birinci mısrada iki ve ikinci mısrada iki olmak üzere dört cümleden oluşmaktadır. Bu cümlelerin parelel olarak benzer ses değerleriyle bitirilmesi, âhenkli bir ifadenin oluşturulmak istendiğini göstermektedir.

\begin{tabular}{|l|l|l|l|}
\hline 1. Cümle: & Haber eylen 'âşılklar $\underline{a}$ & 2. Cümle: & 'sşka gönül viren benem \\
\hline 3. Cümle: & 'Işka bahâ kim yitür $\underline{\underline{e}}$ & 4. Cümle: & 'ışs ma'denin bulan benem \\
\hline
\end{tabular}

Beytin temel anlatım tarzı "emir verme/istekte bulunma", "meydan okuma" ve "üstünlük iddiasında bulunma” biçimindedir. Şairle muhatap (siz) arasında geçen diyalog ifade biçimi, iletişimin "gerçekleri ortaya çıkarma" amacına yönelik olarak düzenlendiğini orta koymaktadır. Bu gerçeklik ise şairin diğer âşıklardan üstün olduğu ve aşkın hakiki değerini anladığı gerçeğidir.

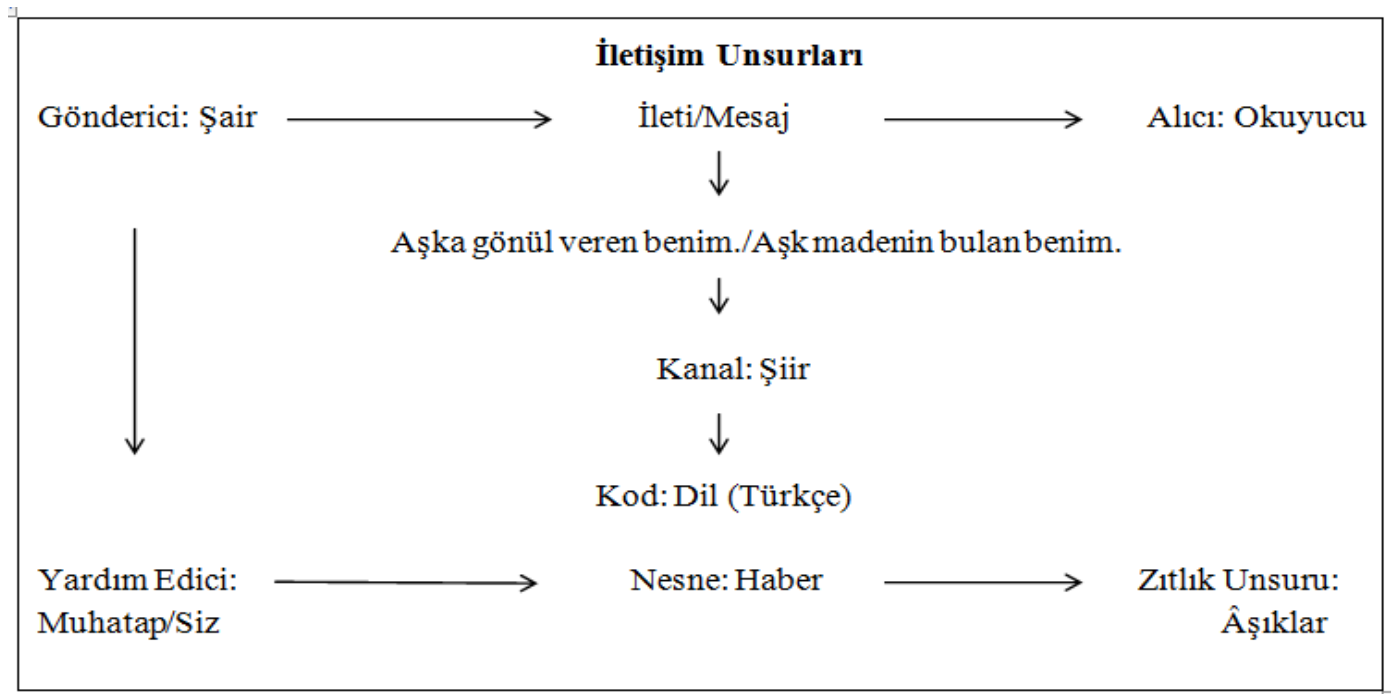




\section{Ferdi KİREMITTÇI 'Yûnus Emre'nin 'Benem' Redifli Bir Gazeli Üzerine Çoğulcu Tahlil}

Denemesi”, Mavi Atlas, 5(2)/2017: 577-625.

Beyitte dikkati çeken bir diğer anlatım biçimi ise dilin şiirsellik işleviyle kullanılması sonucu orta çıkan sanatsal ifadedir. Şairin "istifhâm, tecâhül-i ârif, teşbîh, iştikâk, tenâsüb, tekrîr" sanatlarıyla oluşturduğu bu ifade şekli şiirin muhtevasını hem anlam olarak hem de estetik açıdan kuvvetlendirmiştir.

\begin{tabular}{|c|c|}
\hline İstifhâm & "Işka bahâ kim yitüre" ifadesiyle şair hem soru sormuş hem de bildiği \\
\hline Tecâhül-i ârif & bir gerçeği bilmezden gelmiştir. \\
\hline Teşbîh & “IŞsk”, “maden”e benzetilmiştir. \\
\hline İştikâk & "Âşık, "ışka, "ışk" kelimelerinin kökü aynıdır. \\
\hline Tenâsüb & “Gönül vermek- ‘şsk-âşık” kelimeleri birbiriyle ilişkilidir. \\
\hline Tekrîr & “'Işs" kelimesi beyitte aynı anlamda tekrarlanmıştır. \\
\hline
\end{tabular}

Şiirsel Anlam (Şerh Tabakası): Tasavvuf şiir geleneğinde en fazla işlenen konu "aşk"tır. Aşk, tasavvufî anlamda "sevginin son mertebesi, sevginin insanı tam olarak hükmü altına alması"dır. Tasavvuf düşüncesinde, aşkın varlığın ve insan yaratılışındaki güzelliğin temeli olduğu görüşü hâkimdir. Allah, insanı kendi zatının mutlak güzelliğine ayna olması için yaratmıştır. $O$ hâlde, insan bir güzelliğge bağlanacaksa bu Allah'ın güzelliği olmalıdır. Zaten, insanın yaratılışından itibaren sahip olduğu en büyük sermayesi de sonsuz güzelliğe malik olan Allah'a duyduğu bu aşktır:

\section{Allâh benüm didügine virmişdür 'ş̧k varlıgını}

Kime bir zerre 'ş̧k vire Çalap varlıgı andadur (65/6)

Klâsik şairler, genellikle kendilerini diğer âşıklardan daha üstün mertebede görmüşler, gerçek ve sadık âşığın kendileri olduğu iddiasında bulunmuşlardır. Bunun temel sebebi, aşkın Allah katındaki paha biçilmez değeri ve kulun da bu değerli varlığ elde etme çabasıdır. Yûnus Emre'nin gazeline buna benzer bir iddia cümlesiyle başlaması şüphesiz ki tesadüfî değildir. Şair aslında, hem bu beytin ikinci mısraında hem de gazelin diğer beyitlerinde bu iddiasına açıklık getirmektedir: Yûnus Emre aşkı, kıymetli, pahalı ve bulunması zor cevherlerin bulunduğu bir madene benzetmiştir (teşbîh). Bu madenin bulunduğu yer ise ikinci beyitte geçtiği şekliyle “deniz”dir. Tasavvuf literatüründe deniz/bahr, mutlak varlık olan Allah'1 temsil eder. O hâlde şair, bu cevheri Cenâb-1 Hak'la bütünleşerek elde ettiğini söylemekte, bu madeni keşfeden 
yegâne âşığın da kendisi olduğunu dile getirerek âşıklar içinde müstesna bir yere sahip olduğunu vurgulamaktadır. Ona göre, aşkın kıymetini kendisinden başka hiçbir âşık gerçek manada anlayamamıştır. Bu yönüyle şair diğer âşıklarla kendisi arasında bir zitlık oluşturmuş (tezâd), bu düşüncesini “"Işka bahâ kim yitüre” diyerek "istifhâm” ve "tecâhül-i ârif" sanatlarıyla da desteklemeye çalışmıştır.

Beyitte dikkati çeken ifadelerden biri de "“1şka gönül veren” tabiridir. Şair, bu tabirle gönlünün soyut bir kavram olan "aşk"a bağlandığını söylemiştir. Aslında insan ya dünyevî ve cismanî bir varlığı sever ya da dinî-tasavvufî̀ bir yaklaşımla Allah'a gönül verir. Zaman zaman bu ikisi arasında bir etkileşim de söz konusudur ki buna maddî aşktan manevî aşka geçiş denilir. Şairin beyitte sevilenden ziyade "sevme" fiilini öne çıkarması ve bunu da birkaç defa tekrarlaması (tekrîr) aşk mefhumuna verdiği kutsiyetten ileri gelmektedir. Her ne kadar aşk kavramı, tasavvuf literatüründeki anlamını İslâm'ın ilk dönemlerinden sonra kazanmış ise de tasavvuf çevrelerinde sıkça dillendirilen ve Hz. Muhammed'e ait olduğu nakledilen "Âşık olup da aşkııı gizleyen, iffetini koruyan ve bu hâl üzere iken ölen kişi cennete girer.” sözü bu kavramın kutsal bir değer olarak algılanmasına sebep olmuştur. Bu algının kaçınılmaz bir sonucu olarak Allah aşkını ulaşılması gereken tek hedef olarak gösteren mutasavvıflar, kişiyi bu kutsal hedefe ulaşmaktan alıkoyan her şeyden uzak kalmanın gerekliliğini vurgulamışlardır:

Dünyâyı elden birak olmagıl Hak'dan trak Sermâye kendüsi olmış varlıklar yuyanlara (331/4)

Mutasavvıfların ortak kanaati, tasavvuf yolunun aşk yolu olduğudur. Öyle ki onlar, "İnsanı insan yapan, üç harfli beş noktadır." diyerek "şın" harfinde üç nokta ve "kaf" harfinde iki nokta olmak üzere toplamda beş noktadan oluşan "aşk (عنق)"1 "bekâbillâh" makamının tek vesilesi olarak görmüşlerdir. İnsanın bu vesileyi elde edebilmesi için temiz bir gönle sahip olması gerektiğini belirten mutasavvıflar, Cenâb-1 Hakk'ın “Yerlere göklere sı̆̆madım. Mümin kulumun gönlüne sığdım.” sözünü de buna delil olarak göstermişlerdir. Yûnus Emre de bu beytinde gönlünü aşk madeninin en müstesna mekânı olarak tasvir etmiştir: 
Gönül mi yig Ka'be mi yig eyit bana 'aklı viren

Gönül yigdir zîrâ ki Hak gönülde tutar duragı (366/7)

\section{- İkinci Beyit}

Yir gök tolu bu ‘şsk durur ‘ı̧sksuz hîç nesne yok durur

'Işk bahrisi olubanı denizlere talan benem

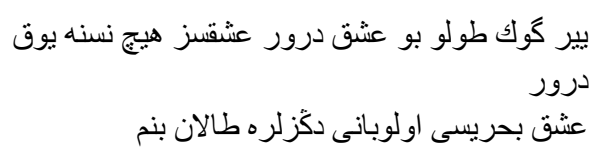

Kelime Bilgisi (Söz Tabakası): 1. yer [T.is.]: Yerzüyü, dünya. 2. gök [T.is.]: İçinde gök cisimlerinin hareket ettiği sonsuz boşluk, sema. 3. tolu [T.sf.]: İçi tamamen dolmuş bulunan. 4. bu [T.sf.]: Yer olarak yakında bulunan bir varlığı işaret eder. 5. '1şk [A.is.]: Bir şeye karşı aşırı düşkünlük. (tasvf.) Allah sevgisi. 6. durur [T.e.f.]: Türkçe ek-fiilin geniş zaman teklik üçüncü şahıs eki olan “-dır, -dir”. 7. '1şk-(sız) [A.is.]: Bir şeye karşı aşırı düşkünlük. (tasvf.) Allah sevgisi. 8. hîç [F.sf.]: Yok olan ya da yok denilecek kadar az olan. 9. nesne [T.is.]: Varlık; smadde; şey; olumsuz cümlelerde hiçbir şey. 10. yok [T.is.]: Var olmayan, bulunmayan. 11. bahrî-(si) [A.is.]: Dalgı̨̧ kuşların adı. 12. ol-(ubanı) [T.zf.f.]: Olup; olarak. 13. deniz-(ler-e) [T.is.]: Derya. (tasvf.) Vahdet; varlık; insân-1 kâmil. 14. tal-(an) [T.f.]: Su içine girmek; derin bir düşünce içine girmek. 15. ben-(em) [T.zm.]: Türkçe teklik birinci şahıs zamiri.

Çeviri (Anlatı Tabakası): 1. Beytin düzyazıya çevrilişi: Yer gök bu aşk (ile) doludur. Aşkssı hiçbir nesne yoktur. Aşk bahrîsi olup denizlere dalan benim. 2. Beytin diliçi çevirisi: Yeryüzü (ve) gökyüzü bu aşk (ile) dopdoludur. (Bundan dolayı, kâinatta) aşksız hiçbir varlık bulunmamaktadır. Ben aşk okyanusunun dalgıç kuşu olarak denizlere daldım (yani cem‘ makamına ererek Allah ile bütünleştim).

Dil ve Anlatım (Üslup Tabakası): Beyitteki kelimelerden ikisi Arapça ('1şk, bahrî), biri Farsça (hîç), diğerleri ise isim soylu Türkçe kelimelerdir. Görüldüğü üzere şair, ilk beyitte takip ettiği Türkçe ağırlıklı söyleyişi bu beyitte de devam ettirmiştir. Zaten bu, Yûnus Emre'nin en önemli üslup özelliğidir. Beyitte üç temel cümle bulunmaktadır. Bunlardan ikisi birinci mısrada, diğeri ikinci mısrada yer alır. Şair, ilk iki yargıyı basit cümle ile üçüncüsünü ise Türkçe zarf-fiilin yer aldığ 1 birleşik cümle ile oluşturmuş; birinci mısradaki iki cümleyi benzer ses değerleriyle bitirerek beytin en önemli âhenk yönünü meydana getirmiştir. 


\begin{tabular}{|c|c|}
\hline 1. Cümle: Yir gök tolu bu 'ışsk durur & 2. Cümle: 'ışksuz hîç nesne yok durur \\
\hline
\end{tabular}

Beyitte dil şiirsellik işlevinde kullanılmıştır. Yani, şair söylemek istediğini çeşitli yöntemlerle estetik ve dikkat çekici hâle getirmiştir. Bu yöntemlerden birincisi, ilk mısradaki "itnâb" yöntemidir. İtnâb, bir maksadı ifade ederken manaya katkı sağlaması için alışılagelen ibareden fazla kelimeler kullanmaktır. Şair, bu mısrada yeryüzünün ve gökyüzünün aşkla dolu olduğunu söyleyerek umuma işaret eden kelimeler kullandıktan sonra, en küçük varlığın bile aşksız olamayacağını ifade ederek hususa işaret eden kelimelere yer vermiş; yani ifadede “zikrü'l-hâs ba'de'l-'âm” denilen anlatım biçiminden yararlanmıştır. (Saraç 2011: 83).

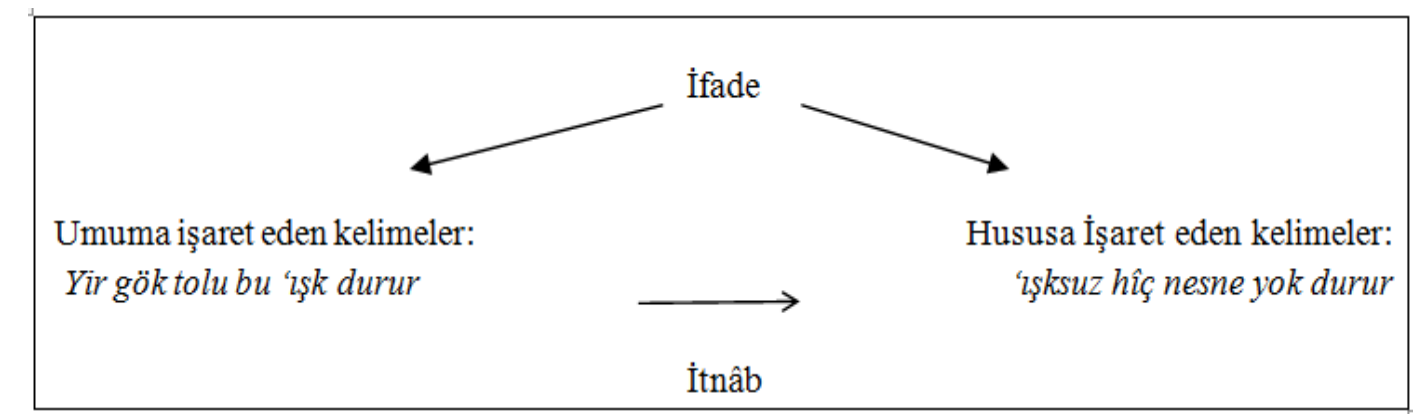

Beyitteki diğer anlatım tarzı ise şiir dilinin vazgeçilmez unsurları olan edebî sanatlarla ve tasavvufî şiirlerde sıkça kullanılan remizlerle sağlanan estetik ve sembolik ifadedir. Şair bu beyitte "tekrîr, tezâd, tenâsüb, teşbîh, kapalı istiâre ve telmîh" sanatlarından yararlanarak anlatımı etkili hâle getirmiş, tasavvufî birer remiz olarak yer verdiği “bahrî”" ve “deniz” kelimeleriyle de anlam zenginliğini temin etmiştir.

\begin{tabular}{|c|c|}
\hline Tekrîr & “'Işk” kelimesi üç defa ve “-durur” eki iki defa yinelenmiştir. \\
\hline Tezâd & "Yir" ile "gök" ve "tolu" ile "yok, hîç" kelimeleri arasında zıtllk vardır. \\
\hline Tenâsüb & "Bahrî", "deniz" ve "talan" kelimeleri arasinda anlam yakınlı̆̆ vardır. \\
\hline Teşbîh & Şair, kendisini “"ışk bahrîsi”"ne benzetmiştir. \\
\hline Kapalı İstiâre & "IŞsk" "deniz"e benzetilmiş, sadece benzetilen söylenmişstir. \\
\hline Telmîh & "Sen olmasaydın felekleri yaratmazdım." sözü hatırlatılmıştır. \\
\hline
\end{tabular}


Şiirsel Anlam (Şerh Tabakası): Bu beyit birinci beytin devamı mahiyetindedir. Birinci beyitte şair, aşka gerçek manada gönül veren kişinin kendisi olduğunu söyledikten sonra bunun sebebi olarak aşk madenini bulduğundan bahsetmişti. Şair, bu beyitte açıklamasına devam etmiş ve aşk madenini bulduğu yeri söylemiştir. Beyitte dikkat edilmesi gereken iki husus vardır. Birincisi ilk mısradaki anlam çağrışımları, ikincisi ise ikinci mısradaki tasavvufî remizlerdir.

Şair birinci mısrada, aşkın yeryüzünü ve gökyüzünü en küçük bir varlık dahi hariç kalmayacak şekilde kuşattığından bahsetmiş; böylece aşkı bütün kâinatın hatta gök cisimlerinin hareketinin bile sebebi olarak gören mutasavvıflarla benzer düşünceye sahip olduğunu ortaya koymuştur. Beyitteki bu ifade, Cenâb-1 Hakk'ın "Sen olmasaydın felekleri yaratmazdım." diyerek kâinatı sevgili bir kulu için yarattığı düşüncesini hatırlatmaktadır (telmîh). Tasavvufî̀ kaynaklarda hadîs-i kudsî olduğu söylenen bu sözden hareketle pek çok sûfî düşünür, kâinâtın asıl yaratılış sebebinin "sevgi” yani “aşk" olduğunu ileri sürmüştür. Yûnus Emre de bu görüştedir. Nitekim o, Dîvân'ın farklı yerlerinde bu düşüncesini, aşkın yer ve gök yaratılmadan önce vücut bulduğunu, ezelden de kadîm olan bir cevher olarak yaratıldığını söyleyerek dile getirmiştir:

\section{Evvel yer-gök yogıdı varıdı 'ş̧k bünyâdı 'Işsk ezelden kadîmdir 'ışk getürdi ne varın (254/3)}

Beyitteki diğer önemli tasavvufî remizler "bahrî" ve "deniz"dir. Tasavvufî şiirlerde sıklıkla kullanılan remizlerin başında "okyanus ve deniz" anlamına gelen "bahr, bihâr, kulzüm, ummân, deryâ, yemm, muhît" gibi kelimeler yer almakta, bu kelimelerle "katre, damla, dalga" gibi kelimeler arasında da paradoksal imajlar oluşturulmaktadır. Tasavvuf literatüründe "bahr" "vahdet"i, "katre, damla ve dalga" ise "kesret"i temsil eder. Buna göre sûfîler, Allah’1 bir deniz, mâsivâyı da bu denizin damlaları ya da dalgaları olarak görmüşler; kendilerini ise bu denize dalan bir "gavvâs (dalgıç)" olarak tahayyül etmişlerdir. Şair, beyitte buna yakın bir kullanımla karşımıza çıkar. Bahrî, deniz veya göllerde yaşayan ördek ve balıkçıl gibi kuşların adıdır. Şair, bu kelimeyi fenâfillâh makamına ulaşmak isteyen kendi nefsi için bir remiz olarak kullanmıştır (teşbîh). Bu tabirle kendisini bir dalgıç gibi düşünen (kapalı istiâre) şair, 
bahrî kuşunun istediği zaman denize dalıp çıkabilmesi gibi, kendisinin de bir sâlik olarak aşk denizine daldığından ve vücudunu Hakk'ın varlığında fani edebildiğinden söz etmiştir.

Denize dalma söz konusu olunca "inci” de akla gelir. Çünkü bahrînin amac1 balık, dalgıcın amacı inci, sâlikin amacı ise Hakk'ın eşyadaki tecellisidir. Şair, sınırsız oluşu, içinde yaşayan varlıkları kuşatması, derinliği ve genişliğinden dolayı bahri, (okyanusu) aşkla ilişkilendirmiş; kendisinin de bu aşk okyanusun bir parçası olduğunu dile getirmiştir. Ona göre, denizdeki inciler içine girmekle elde edilebileceği gibi gerçek manada Allah âşı̆̆ı olabilmek de aşk denizinin içine dalmakla, yani Cenâb-1 Hak’ta yok olmakla (fenâfillâh/vahdet-i vücûd) mümkündür:

Bir kişi âşılk olsa 'ışk deryâsına dalsa

O deryânun içinde gevher bulagan olur (96/4)

Beyitteki "deniz" kelimesi hem "varlık" anlamında kullanılır (ki tasavvufî şiirlerde çoğunlukla mutlak varlık sahibi olan Allah'1 temsil eder) hem de “insân-1 kâmil" anlamını remzeder (ki sûfîlerin nihaî amacı bu mertebeye ulaşabilmektir). Kâmil insan, nefis mertebelerini geçmiş olgun kişidir. Aşk denizine dalarak varlık dairesini tamamlayan bu kişi, bizzat ilâhî tasarrufun da sahibi olmuş; enfüste ve âfâkta istediği gibi seyredebilen, varlık kademelerine inip çıkabilen, canlı-cansız diğer varlıklara müdahale edebilen bir konuma gelmiştir. İşte Yûnus Emre, hem bu gazelinde hem de “devriyye-i arşiyye" türündeki diğer "benem" redifli gazellerinde, "insân-1 kâmil" mertebesine ulaşmış bir sûfî olarak bu enfüsî ve âfâki seyrini anlatmıştır.

\section{- Üçüncü Beyit}

Deniz yüzinden su alup sunvirïrem göklere

Bulutlayın seyrân idüp 'Arş'a yakın varan benem

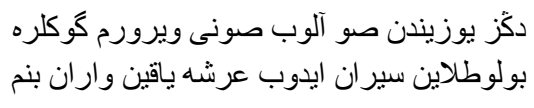

Kelime Bilgisi (Söz Tabakası): 1. deniz [T.is.]: Derya. (tasvf.) Vahdet; varlık; insân-1 kâmil. 2. yüz-(i-n-den) [T.is.]: Bir şeyin üst kısmı; yüzey; satıh. 3. su [T.is.]: Oksijen ile hidrojen karışımından meydana gelmiş, sıvı hâlde bulunan, bütün varlıkların yaşama kaynağı olan akıcı madde. (tasvf.) Marifet, ilâhî feyz, vücut, zat; kâmil nefis. 4. 
al-(up) [T.f.]: Bir nesneyi elle veya araçla tutup yerinden kaldırmak; elde etmek; kazanmak. 5. sunıvir-(ür-em) [T.f.+T.y.f.]: Bir şeyi çabucak ve saygılı biçimde vermek, takdim etmek. 6. gök-(ler-e) [T.is.]: Yeryüzünü örten, ufukla sınırlı, mavi renkli kubbe gibi kapanan boşluk; sema; asuman. 7. bulut-(layın) [T.is.]: Havanın üst katlarında, katı veya sıvı su damlacıklarının meydana getirdiği küme. (tasvf.) Çabalama yoluyla müşahedeye ermeğe neden olan perde. 8. seyrân id-(üp) [A.is.+T.y.f.]: Gezinmek, dolaşmak. 9. 'arş-(a) [A.is.]: En büyük felek (tasvf.) Tecelli mahalli, mutlak varlık. 10. yakın var-(an) [T.sf.+T.y.f.]: Yaklaşmak. 11. ben-(em) [T.zm.]: Türkçe teklik birinci şahıs zamiri.

Çeviri (Anlatı Tabakası): 1. Beytin düzyazıya çevrilişi: Deniz yüzünden su alıp göklere sunuveririm. Bulut gibi seyran edip 'Arş'a yakınlaşan benim. 2. Beytin diliçi çevirisi: (Ben) denizin yüzeyinden su alarak (bunu) çabucak gökyüzüne ulaştırırım. (Ben gökyüzünde) bulut(lar) gibi dolaşırım. (Bu hâlimle) 'Arş'a (yani ilâhî tecelli makamına) yakınlaşan (kişi) benim.

Dil ve Anlatım (Üslup Tabakası): Beyitte iki Arapça (seyrân, 'arş) kelime dışında bütün kelimeler Türk söz varlığına aittir. Bu yönüyle beytin ilk anlamı oldukça açıktır. Ancak, şairin kullandığı dil tasavvufî anlamları gizleyen sembolik bir şiir dilidir ve şair asıl söylemek istediğini yüzeysel anlamın arkasında gizlemiştir. Aslında beyitteki bu gizlilik, Yûnus Emre'nin her iki mısrada sakladığı tasavvufî mazmunlardan kaynaklanmaktadır.

Şair, beyte seyr ü sülûkun önemli safhalarından olan "cem"” ve "cem'ü’l-cem"” kavramları ile bu kavramlarla çok yakından ilişkisi bulunan "devriye" anlayışını gizlemiş; bunların adını zikretmeden belirtilerinden bahsetmiştir. Esasen bu ifade biçimi şairin pek çok şiirinde gözüken "şathiye” üslubunun da bir neticesidir. Çünkü bazı devriyeler şathiyelerle iç içe bir anlatım özelliği göstermekte; devir anlayışının hâkim olduğu bir ifadede, sûfînin terakkî makamlarını (kavs-i 'urûc) katederken takındığı ilâhî tavır, kimi zaman şeriatın zâhirine muhalif gibi addedilmektedir. 


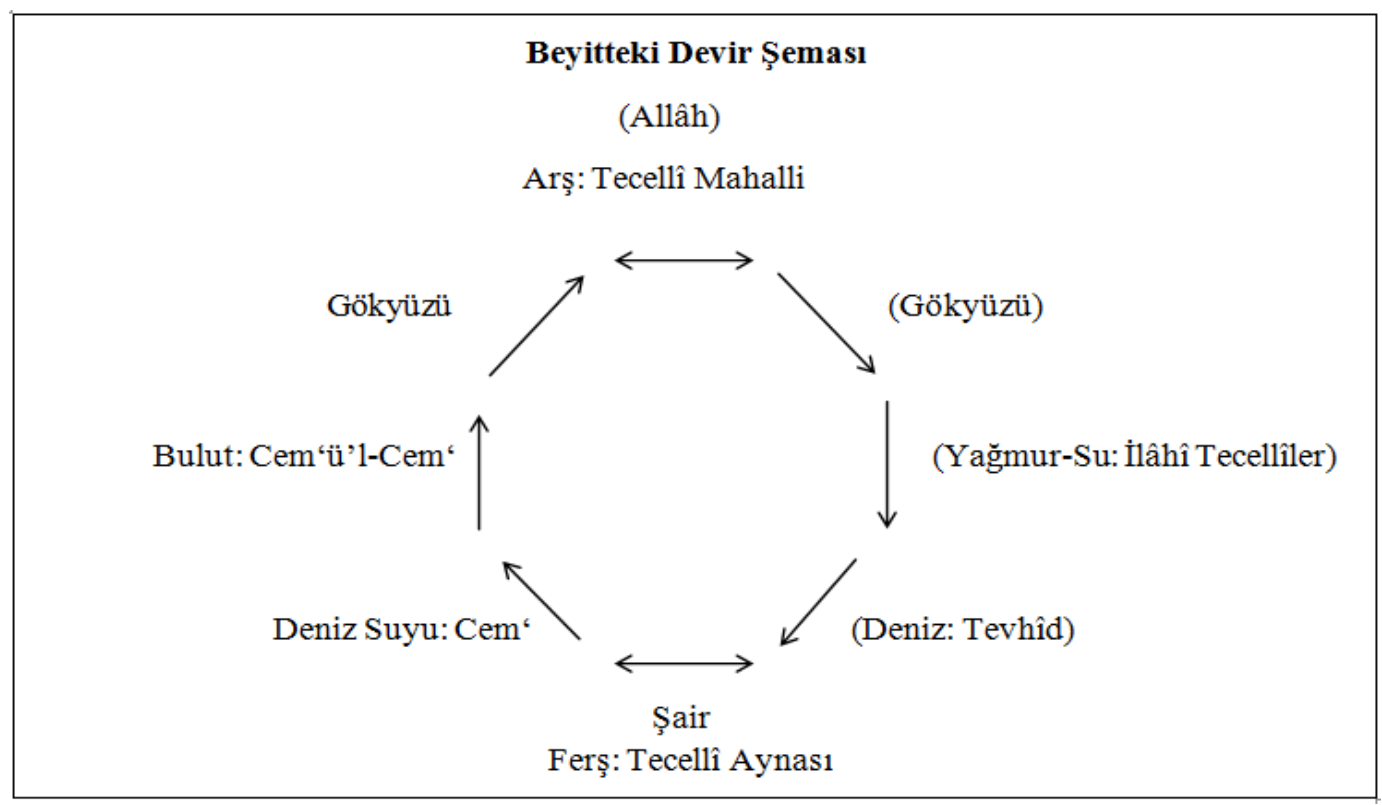

Beytin edebî sanatlar bakımından zengin olduğu söylenemez. Beyitte yer alan yegâne edebî sanat şairin kendisini buluta benzetmesinden ibarettir (teşbîh). Şüphesiz ki bu şairin dili kullanma amaciyla doğrudan ilişkilidir. Şair, beyitte çeşitli ifade biçimleriyle sözünü estetize etme yerine, düşüncesini "gök, deniz yüzü, su, bulut ve 'arş” kelimeleriyle sembolize etme yolunu tercih etmiştir.

Şiirsel Anlam (Şerh Tabakası): Beyitteki en önemli şiirsel anlam, tabiattaki bir döngüsel gerçekliğin tasavvufî kavramlarla ilişkilendirilmesi sonucu elde edilen çağrışımlardır. Malum olduğu üzere, dünyanın en önemli yapı taşı sudur ve Cenâb-1 Hak yeryüzüyle gökyüzü arasında su merkezli döngüsel bir bağ kurmuştur. Buna göre Allah, yeryüzündeki suları, buharlaşma yoluyla gökyüzündeki bulutlarda biriktirir ve ihtiyacı olan varlıklara en münasip zamanda tekrar yağmur şeklinde gönderir. Yûnus Emre, pek çok sûfî şairde görüldüğü gibi, bu tabiî gerçekliği Cenâb-1 Hak'la mâsivâ arasındaki devir ilişkisinin bir işareti olarak düşünmektedir.

Tasavvuf anlayışında denizin tamamı "tevhîd"i, denizin kabarçıkları ya da suyu ise "kesret"i temsil eder. Nasıl ki denizin bir kısmı buharlaşma yoluyla gökyüzüne çıkıp tekrar yağmur şeklinde yeryüzüne iniyorsa, başta insan olarak bütün varlıklar da yeryüzüne Allah tarafindan gönderilmiş ve ölümle tekrar ona dönmek mecburiyetinde 
bırakılmıştır. Kur'ân-1 Kerîm'de “Onlar Allah'tan geldiler ve yine Allah'a dönecekler (Bakara 2/156)." âyetiyle anlatılan bu hakikat, mutasavviflar tarafindan "kavseyn"in birleşmesiyle oluşan bir daire ile izah edilmiş; bu daire tenezzül makamları (kavs-i nüzûl) ve terakki makamları (kavs-i 'urûc) şeklinde iki kısımda ele alınmıştır. İlk tecellisiyle "akl-1 küllî”yi (Muhammedî nur) yaratan Allah, bu tecellisini madenlere kadar indirmiştir. Kulun görevi de terakkî makamlarını madenlerden başlayarak "insân-1 kâmil"e kadar tamamlamaktır. Bu makamları geçerek kemal mertebesine ulaşan insan, istediği anda "seyr-i enfüsî”ye ve "seyr-i âfâkî””ye girebilmekte; böylece Cenâb-1 Hakk'1 "cem"” ve "cem'ü’l-cem“" makamlarında müşahede edebilmektedir.

İşte Yûnus Emre pek çok şiirinde olduğu gibi, bu beytinde de "devr" nazariyesinden hareketle kendi seyr ü sülûkundan bahsetmiş; deniz yüzünden su alıp göklere sunduğunu ve bulutlar gibi seyran ederek arşa yakınlaştığını söylerken aslında "cem" ve "cem'ü'l-cem" makamlarında Cenâb-1 Hakk'ta yok olduğunu belirtmiştir. Çünkü "bulut" mecazen Allah'ın rahmet ve ihsanı anlamlarına gelirken tasavvuf literatüründe ise sûfîyi müşahedeye ulaştıran perde olarak değerlendirilir. O hâlde, şairin kendisini bulutlara benzeterek (teşbîh) bahsi geçen makamlarda olduğunu sembolize etmiştir.

Ka'be vü büt-îmân benem çarh uruban dönen benem

Bulut olup göge agan yagmur olup yagan benem (194/1)

Beytin zâhir manasına bakılınca, bir insanın denizden su alarak göklere sunmasının imkânsız olduğu ve bunun sadece Cenâb-1 Hak tarafindan gerçekleştirebileceği âşikârdır. Ancak, daha önce belirtildiği gibi bu tür ifadeler "cem"” makamındaki sûfîlerin vecd ve istiğrak hâlinde söyledikleri şathiye içerikli sözlerdir. Mutasavvifların ifadesiyle "cem"” mâsivâyı Allah ile kaim olarak görme, "cem'ü'lcem"” ise Hak'tan başka hiçbir şeyi görmeme hâlidir. Bu hâllerle hâllenen bir sûfînin ilk bakışta dinî ve şerî inanışlara aykırı gibi görünen bu çeşit beyanlarda bulunması, Hak ile kul arasındaki ikiliğin ortadan kalkmasıyla, yani Hakk'ın "kendinden kendine” sözler sarfetmesiyle ilişkilendirilmektedir. Allah, kendi nurunu insân-1 kâmilin alnına koymuştur. $\mathrm{Bu}$ insana o kadar büyük bir tasarruf yetkisi vermiştir ki kendi 
özelliklerinden bahseden bir kâmilin Allah'ın diliyle konuştuğu görülür. Kul-sultan ikiliğinden bahsedilemeyen bu makam, aslında vahdet-i vücûdun idrak edildiği en yüksek noktadır. Yûnus Emre'nin deyimiyle bu makamda cân ile cânân arasında herhangi bir fark bulunmamaktadır:

Yûnus bu cismüm adıdur cisim anun bünyâdıdur Adum eger sorarıan bilgil câna cânân benem (199/5)

\section{- Dördüncü Beyit:}

Yıldırım olup şakıyan gökde melâ'ik toklyan

ييلديريم اولوب شاقييان كو كده ملأثك طوقييان Bulutlara hüküm sürüp yagmur olup yagan benem

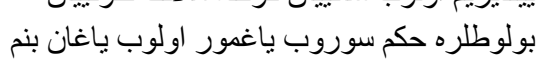

Kelime Bilgisi (Söz Tabakası): 1. yıldırım [T.is.]: Bulutlarda toplanan elektriğin kuvvetli bir ışık yayarak gümbürtülü bir şekilde yere boşalması olayı; şimşek. 2. ol-(up) [T.f.]: İsimlerden sonra geldiğinde ... hâline gelmek. 3. şakı-(y-an) [T.f.]: Çakmak; parlamak; 1şık saçmak. 4. gök-(de) [T.is.]: İçinde gök cisimlerinin hareket ettiği sonsuz boşluk; uzay; feza. 5. melâ'ik [A.is.]: Melekler. 6. tokı-(y-an) [T.f.]: Vurmak, dövmek. (mecaz) Bir eseri, en ince noktalarına kadar özen göstererek ortaya çıkarmak. 7. bulut-(lar-a) [T.is.]: Havanın üst katlarında, katı veya sıvı su damlacıklarının meydana getirdiği küme. (tasvf.) Çabalama yoluyla müşahedeye ermeğe neden olan perde. 8. hüküm sür-(üp) [A.is.+T.f.]: Hâkim olmak, hâkimiyetini devam ettirmek, etkisini yürütmek. 9. yagmur [T.is.]: Havaküredeki su buharının yoğuşarak damlacıklar hâlinde yere düşmesiyle oluşan yağış. (mecaz) Çokluk, bolluk. 10. ol-(up) [T.f.]: İsimlerden sonra geldiğinde ... hâline gelmek. 11. yag-(an) [T.f.]: (Kar, yağmur, dolu vb. için) gökten yere doğru inmek. 12. ben-(em) [T.zm.]: Türkçe teklik birinci şahıs zamiri.

Çeviri (Anlatı Tabakası): 1. Beytin düzyazıya çevrilişi: Yııldırım olup şakıyan, gökte melâik tokıyan, bulutlara hüküm sürüp (ve) yağmur olup yağan benim. 2. Beytin diliçi çevirisi: Yıldırım olup çakan ve gökyüzünde 1ş1k(lar) saçan, gökteki melekleri cezalandıran (veya onları gökyüzünde yaratan), bulutlara istediği gibi hükmederek yağmur şeklinde yağan benim. 
Dil ve Anlatım (Üslup Tabakası): Beyitte yer alan kelimeler, Arapça "melâ'ik" kelimesi hariç Türkçedir.. Beytin en önemli ifade tarzı şathiye üslubudur. Bu üslubun gereği olarak Allah’ta yok olup onun icraatlarına sahip çıktığını belirten şair, beyitteki ifadesini kendisini “yıldırım”a ve “yağmur”a benzeterek yaptığ 1 "teşbîh” sanatı üzerine bina etmiştir.

Şiirsel Anlam (Şerh Tabakası): Bu beyit içerik olarak bir önceki beytin devamı mahiyetindedir. Beyitte şair, "cem'ü’l-cem"” makamında bulunduğunu, şathiye içerikli sözlerden olan "gökte melâ'ik dokumak" ve "bulutlara hüküm sürmek”le göstermiştir. Beyitteki “tokıyan” kelimesinin "tevriye”li kullanıldığını söylemek mümkündür. Kelimenin "dövmek, ceza vermek" ile "ortaya çıkarmak, yaratmak" gibi iki farklı anlamı vardır ve bunların her ikisi de beytin genel anlamına uygun düşmektedir. Çünkü yarattığı varlıkları (beyit için düşünülürse melekleri) istediği gibi cezalandırabilen ya da onlar1 gökyüzünde sadece kendisine itaat etmek ve daima hayra vasita olmak üzere yaratan Allah'tır.

Yıldırım olup şaklyan kakiyup nefsin dokıyan

Yirün ka'rında berkiyen şol agilu ılan benem (194/3)

Beyitteki diğer çağrışım değeri olan kelimeler ise "yıldırım” ve "yağmur"dur. Yıldırım, çaktığında 1şı̆̆ını gökyüzüne yaymasıyla (en azından yeryüzünden bu şekilde görülmesiyle) Allah'ın Celâlî isimlerini, yağmur ise canlı-cansız bütün varlıkların yaşam kaynağı olması ve bu yönüyle Allah'ın merhametini ifade eden "rahmet"le özdeşleşmesiyle onun Cemâlî isimlerini hatırlatmaktadır. Şair, bu kelimelerin varlıklar üzerindeki kuşatıcılığından hareketle Allah'ın isim ve sıfatlarının kâinatın her tarafinda bulunduğundan bahsetmiş; kendisini onun adına konuşturduğu şathiye üslubuyla da mahlukat üzerinde tasarruf sahibi olan yegâne varlığın Cenâb-1 Hak olduğunu dile getirmiştir: 


\section{- Beşinci Beyit}

Gördüm gögün meleklerin her biri bir cünbişdedir

Hak Çalab'un zikrin ider İncîl ü hem Kur'ân benem
كوردم كَ كاكث ملكلرن هر برى بر جنبشدمدر حق جالابكث ذكرن ايدر انجيل و هم قرى برآن بنم

Kelime Bilgisi (Söz Tabakası): 1. gör-(dü-m) [T.f.]: (Bir şeyin oluşuna veya var olduğuna) Şahit olmak, müşâhede etmek. (tasvf.) Hakk'ın gönüllerde hazır olması; mana âleminde görülen ulvî ve ruhî hâller. 2. gög-(ün) [T.is.]: İçinde gök cisimlerinin hareket ettiği sonsuz boşluk; uzay; feza. 3. melek-(ler) [A.is.]: Gözle görülüp elle tutulmayan, yiyip içmeyen, cinsiyet farkı bulunmayan, sadece Allah'a itaat etmek ve daima hayra vasıta olmak üzere yaratılmış olan sayısız nuranî varlıklardan her biri. 4. her bir-(i) [F.sf.+T.is.]: Ayrı ayrı, tek tek, hepsi. 5. bir [T.is.]: Ortaklaşa; birbirine denk, ayn1. 6. cünbiş-(de-dir) [F.is.]: Hareket etmek; eğlence. 7. Hak Çalab-(un) [A.is+T.is.]: Allâhü Taâla. 8. zikr-(i-n) id-(er) [A.is.+T.y.f.]: Anmak, hatırlamak. (tasvf.) Allah kelimesini tekrarlamak; Allah'1 unutmamak ve gaflet hâlinde olmamak. 9. İncîl [A.is.]: Hz. İsâ'ya indirilen kutsal kitap. 10. ü [F.bağ.]: Ve. 11. hem [F.bağ.]: bir de. 12. Kur'ân [A.is.]: Hz. Muhammed'e indirilen Müslümanların kutsal kitabı. 13. ben-(em) [T.zm.]: Türkçe teklik birinci şahıs zamiri.

Çeviri (Anlatı Tabakası): 1. Beytin düzyazıya çevrilişi: Gördüm gögün meleklerin(i) (ki) her biri bir cünbüştedir. Hak Çalab'ın zikrini ider(ler). İncîl ve hem Kur'ân benim. 2. Beytin diliçi çevirisi: a. Göğün meleklerinin her birini aynı iş içinde/harekette (veya eğlencede) gördüm ki Allah'1 zikrederler. (Bunları görme makamına işaret eden) İncîl ve Kur'an benim. b. Göğün meleklerinin her birini aynı iş içinde/harekette (veya eğlencede) gördüm. Ben (her daim) Allah'1 zikreden (yani bana onu hatırlatan) İncîl ve Kur'ân'ım.

Dil ve Anlatım (Üslup Tabakası): Bu beyitteki Türkçe olmayan kelime sayısının daha önceki beyitlerle kıyaslanınca daha fazla olduğu görülmektedir. Şüphesiz ki bu, şairin beyitte anlattıklarıyla alakalıdır. Her ne kadar Yûnus Emre, zaman zaman dinî-tasavvufî̀ bazı kavramların (beyitteki "görmek=müşâhede" ve "Çalab=Allâh" kelimeleri gibi) Türkçe karşılıklarını kullanmaya çalışsa da işlediği konular çoğu kez onu bu kavramların orijinallerinden yararlanmaya da itmektedir. Nitekim beyitteki 
Türkçe söz varlığına ait olmayan kelimelerin tamamı birer dinî-tasavvufî̀ terimdir (melek, Hak, zikr, İncîl, Kur'ân). Beyitteki en dikkat çekici üslup özelliği, belâgat kitaplarında "sihr-i helâl" başlığı altında ele alınan anlatım tekniğidir. Bu teknikle şair, ikinci mısraın başındaki "Hak Çalab'un zikrin ider" tabirini hem kendisinden önceki kelimelerle birlikte hem de kendisinden sonraki kelimelerle birlikte anlam verilebilecek şekilde kullanmış, böylece beyitteki anlam zenginliğini tesis etmiştir. Şairin "cünbiş" kelimesiyle "tesbih etmek" anlamını çağrıştırarak "göklerde ve yerlerdeki bütün varlıkların Allah'1 zikretmesi” ile ilgili âyetleri hatırlatması (telmîh) da bu anlam zenginliğinin bir sonucu olarak gözükmektedir.

\begin{tabular}{|l|l|}
\hline \multirow{2}{*}{$\begin{array}{l}\text { Hihr-i } \\
\text { Helâl }\end{array}$} & \begin{tabular}{l} 
1. Gördüm gögün meleklerin her biri bir cünbişdedir (ki) Hak Çalab'un zikrin ider. \\
\cline { 2 - 3 } Telmîh
\end{tabular} \\
\hline $\begin{array}{l}\text { 2. Hak Çalab'un zikrin iden İncîl ü hem Kur'ân benem. } \\
\text { hatırlatılmasl. ve yerlerdeki bütün varlıkların Allah'ı zikretmesi” ile ilgili ayetlerin }\end{array}$ \\
\hline
\end{tabular}

Şiirsel Anlam (Şerh Tabakası): Şair beyte kesin bir yargı bildiren "gördüm" kelimesiyle başlamıştır. Kelimenin Arapça karşıllı̆ 1 "müşahede"dir. Tasavvufî bir kavram olan bu kelime, Cenâb-1 Hakk'ın gönüllerde hazır olması, onun cemâlinin kalp gözüyle temaşa edilmesi, hakka'l-yakîn hâli ve kimi sûfîlerce de mana âlemindeki ulvî ve ruhî hâlleri görme makamı olarak açıklanmıştır. Dolayısıyla şair, kendi seyr ü sülûkunun “"ayn-1 cem”" mertebesinde bulunduğunu bu kelimeyle bir kez daha belirtmiştir. Yûnus Emre, bu makamda gördüklerine açıklık da getirir. Onun müşahedesiyle gökteki meleklerin her birisi bir cünbüştedir. Melekler zikir ehlidirler ve onların yegane eğlencesi Allah'ın adını tekrarlamaktır. Hatta onlar bu vazifelerini zikir meclislerindeki erenlerle birlikte de sürdürürler:

Mevlânâ sohbetinde sâzıla işret oldı

Ârif ma’nâya daldı çün biledir ferişte (301/7)

Yûnus Emre'nin diğer şiirleri de dikkate alındığında onun ilâhî kitapların her birini manevî birer makam olarak değerlendirdiği görülür. Bu anlayış çerçevesinde, semavî kitaplar kâmil insanın vücudundan başka bir şey değildir: 


\section{Tevrât'ıla İncîl'i Zebûr'ıla Furkân'ı \\ Bunlardagı beyânı cümle vücûdda bulduk (133/6)}

Fenâfillâh makamını yaşayan şair, sülûku esnasında kendi sırrını "tevhîd-i esmâ" ve “tevhîd-i zât”a işaret eden İncîl'de ve Kur'ân'da görmüş, bu hâlini de nefsini bu kitaplarla özdeşleştirerek dile getirmiştir. Ona göre bu semavî kitapların gayesi ledünnî ve manevî olup sâlikin makamını yansıtmaktır. Semavî kitapları yazanın ve Kur'ân'da yazılanın (ki beyitte bu Allah'ın zikri olarak belirtilmiştir) kendisi olduğunu söyleyen şair, Kur'ân'nın insanın, insanın da Kur'ân'ın hakikatı olduğunu düşünmektedir:

Halk içinde dirlik düzen dört kitâbı togru yazan Ag üstine kara dizen ol yazılan Kur'an benem (198/8)

\section{- Altıncı Beyit}

Gördüm diyen degül gören bildüm diyen degül bilen Bilen oldur gösteren ol 'işka esîr olan benem

$$
\begin{aligned}
& \text { كوردم ديين دكل كَورن بيلام ديين دكل بيلن } \\
& \text { بيلن اولدر كَسترن اول عثقه اسير اولان بلنم }
\end{aligned}
$$

Kelime Bilgisi (Söz Tabakası): 1. gör-(dü-m) [T.f.]: (Bir şeyin oluşuna veya var olduğuna) Şahit olmak, müşâhede etmek. (tasvf.) Allah'ın cemâlinin kalp gözüyle temaşa etmek; Hakk'ın gönüllerde hazır olması; mana âleminde görülen ulvî ve ruhî hâller. 2. di-(y-en) [T.f.]: Anlatmak, ifade etmek. 3. degül [T. ed.]: Cümlenin anlamının olumsuz hâle getiren kelime; ek-fiilin olumsuzu. 4. gör-(en) [T.f.]: (Bir şeyin oluşuna veya var olduğuna) Şahit olmak, müşâhede etmek. 5. bil-(dü-m) [T.f.]: Bir şey hakkında bilgisi olmak, o şeyi öğrenmiş bulunmak. (tasvf.) Nefsini bilerek hakikatı bulmak ve anlamak. 6. di-(y-en) [T.f.]: Anlatmak, ifade etmek. 7. degül [T. ed.]: Cümlenin anlamını olumsuz hâle getiren kelime; ek-fiilin olumsuzu. 8. bil-(en) [T.f.]: Bir şey hakkında bilgisi olmak, o şeyi öğrenmiş bulunmak. 9. bil-(en) [T.f.]: Bir şey hakkında bilgisi olmak, o şeyi öğrenmiş bulunmak. 10. ol-(dur) [T.zm.]: Üçüncü teklik şahıs zamiri “o”. 11. göster-(en) [T.f.]: Görülmesini sağlamak; öğretmek, bildirmek, anlatmak. 12. ol [T.sf.]: İşaret sıfatı “o". 13. "1şk-(a) [A.is.]: Bir şeye karşı aşırı düşkünlük. (tasvf.) Allah sevgisi. 14. esîr ol-(an) [A.is.+T.y.f.]: Kendini kaptırıp müptela olmak, buyruğu altına girmek; âşık. 15. ben-(em) [T.zm.]: Türkçe teklik birinci şahıs zamiri. 
Çeviri (Anlatı Tabakası): 1. Beytin düzyazıya çevrilişi: Gördüm diyen degül gören, bildüm diyen degül bilen. Bilen oldur (ki) gösteren, ol '1şka esîr olan benem. 2. Beytin diliçi çevirisi: Gördüm diyen (kişi), gören (kişi) değil(dir). Bildim diyen (kişi), bilen (kişi) değil(dir). (Gerçek) bilen, (bildiğini) göster(ebil)en (kişidir). (O kişi) aşka esir olan(dır) ki (o da) benim.

Dil ve Anlatım (Üslup Tabakası): Şairin bu beyitte de Türkçe söyleyiş̧e özen gösterdiği görülür. “'Işk”" ve “esîr” kelimesi dişındaki bütün kelimeleri Türkçe söz varlığından seçen şair, bir önceki beyitte dikkati çeken Türkçe tasavvufî kavramlara yer verme özelliğini bu beyitte de devam ettirmiş; "gör-, bil-, göster-" kelimelerini en önemli tasavvufî terimlerden olan "müşâhede, mârifet, 'aşk" kavramlarını temsil edecek şekilde kullanmıştır. Beyitte birinci mısrada iki olumsuz, ikinci mısrada ise iki olumlu yarg1 olmak üzere toplamda dört "iddia” yarg1sı bulunmaktadır. Bu yargılar gazelin birinci beytinde olduğu gibi "haber verme" ve "meydan okuma" amacına yönelik olarak oluşturulmuştur. Beytin âhenk bakımından da üst seviyede olduğu göze çarpar. Bu âhenk ses ve kelime tekrarlarıyla (tekrîr) sağlanmıştır. Bu tekrarlar birinci mısradaki bütün kelimelerin ikişer kez ve her iki cümleyle içi içe olacak şekilde yinelenmesi, ikinci mısraya birinci mısranın son kelimesiyle başlanması ve bu mısradaki "ol" kelimesinin üç defa tekrarlanması, her iki mısrada yer alan “-en” sıfat-fiil ekinin de yedi defa kullanılmasıyla gerçekleştirilmiştir:

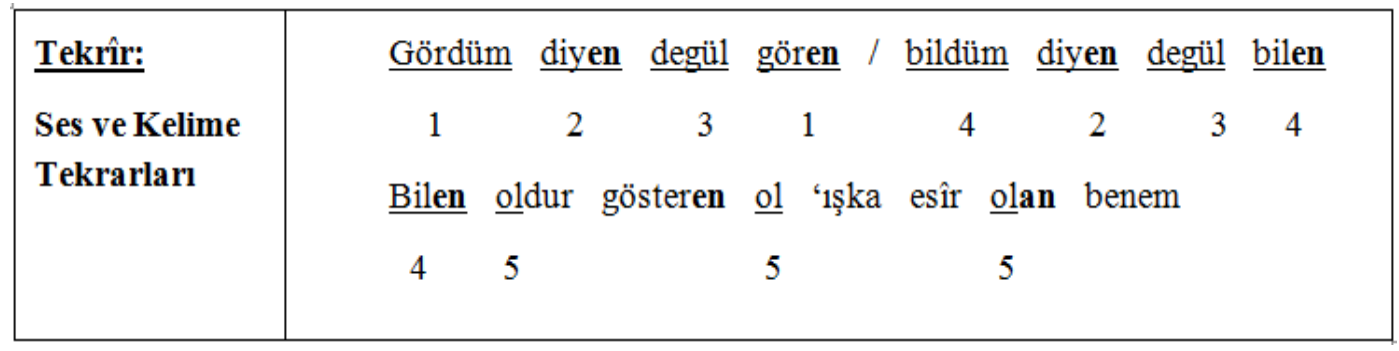

Şiirsel Anlam (Şerh Tabakası): Bu beyitte şair, kelâm âlimlerinin ve sûfî müfessirlerin farklı görüşler ileri sürdükleri "müşâhede" konusu ile "tevhîdin/imanın mertebeleri” üzerinde durmuştur. Müşâhede, gözle görmek ve seyretmek anlamındadır. Rü'yetullâh tabiriyle de ifade edilen bu kavramla ilgili olarak “Allah'ın cemâlinin kalp 
gözüyle temaşası, sâlikin kendisini kaybedip Hakk'ı bulması, eşyayı tevhîd deliliyle görmek, hakka'l-yakîn hâli...” gibi farklı tanımlamalar yapılmıştır. Yûnus Emre, pek çok mutasavvıf gibi, Allah'ın dünyada -hayatta iken- görülebileceğini düşünmektedir:

Kamu 'âlem ümîd tutar âhiretde görem diye

Yûnus eydür dervîş olan bunda Hakk'ı buldı gider (87/8)

Ancak o, dinin zâhirinde kalanları tenkit ederek bu kişilerin Allah'1 bilme ve görme iddialarının gerçek dışı olduğunu savunur. Çünkü şaire göre yaşantıya aksetmeyen ve davranışlarla gösterilmeyen bir bilginin Allah katında hiç bir kıymeti yoktur. Şair, burada "Ey iman edenler! Yapmayacağınız şeyleri niçin söylüyorsunuz (Saff, 61/2)?" âyetini hatırlatmaktadır (telmîh). Yûnus Emre, beyitte dinî bilgiyi yaşama şeklini “aşka esir olma” şeklinde açıklamıştır. Ona göre Hakk'a gönül veren ve onunla yüz yüze görüşen kişinin Allah aşkıyla cümle varlıktan mat olması -yani onlarla bağını keserek sadece yaratana esir/kul olmas1- gerekmektedir:

Ol işlere eli iren Hak 'ş̧kına gönül viren

Dostın yüze yüz gören cümle varllktan mat olur (45/7)

Beyitteki "bil-, gör-, göster-” kelimeleri, tasavvufî literatürde "bilmek-bulmakolmak" şeklinde tabir edilen üç mertebeye de işaret eder. Bilmek, hakikati anlamaktır. Bulmak, şuhûd ve '1yân ile Allah'1 görmektir. Olmak, ikiliksiz birliğe ulaşmaktır. Yûnus Emre, “olma”nın Allah aşkıyla “ölmek”ten geçtiğini düşünür:

Ne gelmegün gelmek durur ne bilmegün bilmek durur Son menzilün ölmek durur tuymadun 'işkdan bir eser (28/7)

$\mathrm{Bu}$ mertebeler, tevhîdin “ilme'l-yakîn, ayne'l-yakîn, hakka'l-yakîn” mertebeleriyle de ilgilidir. Ancak, Yûnus Emre şiirlerinde “ilme'l-yakîn"den söz etmez ve tamamen Hakk'1 bilmek, bulmak ve Hak'ta olmak makamları olan "ayne'l-yakîn” ve “Hakka'l-yakîn”den bahseder. Ona göre kâmil insan, bu basamakları geçerek bir ile bir olabilen kişidir: 
Beyitte şair kendisini bir esire benzetmiştir (teşbih). Esir, zincire vurulmuş mahkûmdur. Aynı zamanda eski dönemlerde delilerin bir çılgınlık yapmasınlar diye ellerinden ve ayaklarından zincirlendikleri de bilinmektedir. İşte şair, aşkın verdiği "tutsaklık ve mecnunluk" ile mahkumlara ve delilere vurulan "zincir" ilişkisini "aşkın esiri olmak" tabiriyle açıklamış, kendisinin de bu hâl içre olduğunu belirtmiştir:

'Işsun zencîrini üzem delü olam taga düşem

Sensin dün ü gün endîşem bana seni gerek seni (381/4)

\section{- Yedinci Beyit}

Sekiz uçmak 'âş̧ılara köşk ü sarâydur anlara

Mûsî'leyin hayrân olup Tûr Tagı'nda kalan benem
سكز اوجماق عانقلاه كوشك و سر ايدر آنلره

Kelime Bilgisi (Söz Tabakası): 1. sekiz [T.is.]: Yedi ile dokuz arasında yer alan tam sayı. 2. uçmak [T.is.]: Cennet; "gölgelik bahçe" anlamında olup ahirette müminlerin gidecekleri yerin adıdır. (tasvf.) Kalbin duyduğu manevî zevk ve hazlar; Allah'a vuslat. 3. 'âşık-(lar-a) [A.is.]: Aşırı seven kimse. (tasvf.) Her türlü dünya gailesi ve dünya nimeti sevgisinden uzaklaşmış, bütün sevgisini Allah'a adamış derviş. 4. köşk [T.is.]: Bahçe içine yapılmış gösterişli ve süslü ev. 5. ü [F.bağ.]: Ve. 6. sarây-(dur) [F.is.]: Görkemli büyük konut. 7. a-(n-lar-a) [T.zm.]: Türkçe teklik üçüncü şahıs zamiri “o”. 8. Mûsî-(leyin) [A.öz.is.]: Semavî kitaplardan Tevrât'ın kendisine indirildiği Hz. Mûsâ (gibi). 9. hayrân ol-(up) [A.sf.+T.y.f.]: Şaşırmak; kendinden geçmek. (tasvf.) Kalbe gelen bir tecelli sebebiyle sâlikin düşünemez ve muhakeme edemez hâle gelmesi. 10. Tûr Tagi-(n-da) [A.öz.is.+T.is.]: Allah'ın Hz. Mûsâ ile konuştuğu dağ. (tasvf.) Nefis; ilâhî hakikat; feyz ve marifet kaynağ1; tecelli mahalli; gönül, vücut. 11. kal-(an) [T.f.]: (Olduğu yerde ve olduğu hâlde) durmak. 12. ben-(em) [T.zm.]: Türkçe teklik birinci şahıs zamiri.

Çeviri (Anlatı Tabakası): 1. Beytin düzyazıya çevrilişi: Sekiz (kat) uçmak âşıklara köşk ü saraydır. Mûsâ'layın hayrân olup Tûr Tagı'nda kalan benim. 2. Beytin diliçi çevirisi: Âşıklar için sekiz (kat) cennet köşk ve saraydır. Ben Tûr Dağı'nda kendinden geçerek kalan Mûsâ gibiyim. 
Dil ve Anlatım (Üslup Tabakası): Beyitte Arapça, Farsça ve Türkçe kelimeler birlikte kullanılmıştır. Ancak Türkçe olmayan kelimeler beyitteki Türkçe söyleyişe halel getirecek düzeyde değildir. Hatta şairin "cennet” kelimesi yerine "uçmak" kelimesini tercih etmesi onun daha önceki beyitlerde gözüken Türkçe tasavvufî̀ terim kullanma tarzının devamı mahiyetindedir. Ayrıca, beyitte kastedilen gerçek anlamın "uçmak, Mûsâ, Tûr, hayrân" gibi dinî kelimelere yüklenen tasavvufî manalarla keşfedilebilmesi, şairin beyitte oluşturduğu anlam derinliğinin bir sonucudur. Beyitte ifadeyi etkili hâle getiren bazı anlatım tekniklerinden de yararlanıldığı görülür. $\mathrm{Bu}$ tekniklerin başında birinci mısradaki bazı kelimelerle ikinci mısradaki kelimeler arasında kurulan ilişki (leff ü neşr) yer alır. Şair, öncelikle kendisini Hz. Mûsâ'ya benzetmiş (teşbîh), sonra da birinci mısradaki "âşıklar" kelimesi ile kendisine benzetilen konumundaki "Mûsâ" arasında, "sekiz uçmak" ile de "Tûr Tagı” arasında anlam bağı oluşturmuştur. Çünkü Hz. Mûsâ'nın tecelliye mazhar olduğu yer "Tûr Dağı” olduğu gibi, âşıkların Cenâb-1 Hakk'ın isim ve sıfatlarını tam manasıyla müşahede edecekleri yer de "sekiz kat cennet”tir. Bu bağla alakalı olarak, şairin birinci mısradaki genel ifadeyi ikinci mısrada özelleştirdiği (itnâb), yani belagat tabiriyle “zikrü'l-hâs ba'de'l-âm” denilen umuma işaret eden lafizdan sonra hususa işaret eden lafza yer vererek düşüncesini daha etkili bir biçimde ifade etme yoluna gittiği söylenebilir.

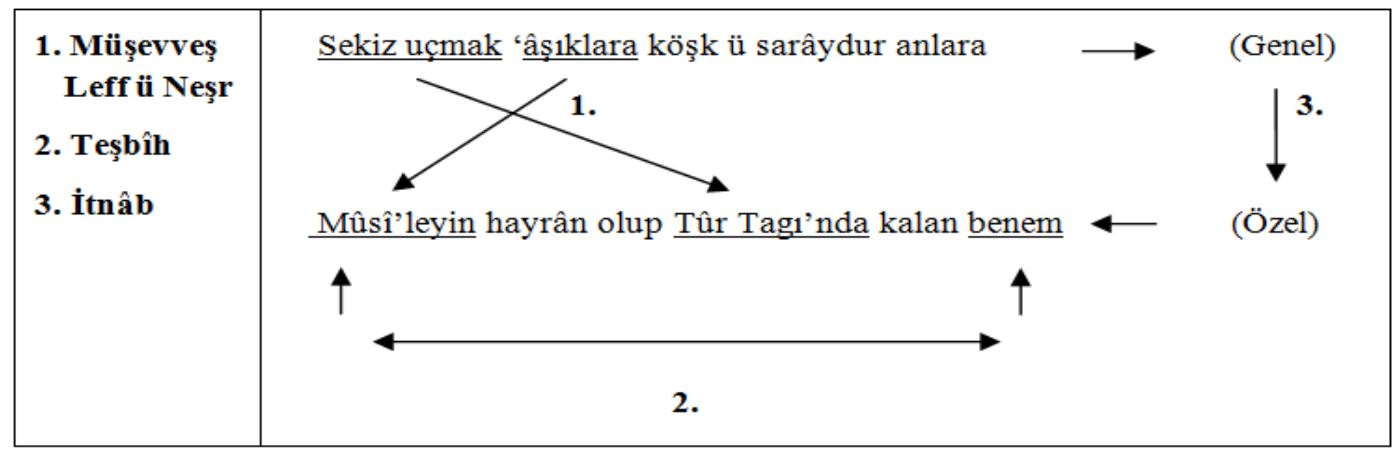

Şiirsel Anlam (Şerh Tabakası): Cennetin "Huld, Me’vâ, Na'îm, Âliye, Adn, Firdevs, Dâru's-Selâm ve Hayevân” olmak üzere sekiz tabakasından bahsedilir. Yûnus Emre'nin anlayışına göre uçmak/cennet, Allah'a ulaşma yolunda bir vasitadır. Hatta o, zaman zaman bu kelimelerle Allah’a vuslatı kasteder. Cennetteki köşk ve saraylar, 
müminlere verileceği vadedilen mükâfatı temsil etmektedir. Ancak, şairin ifadesiyle âşıklar köşklere ve saraylara tenezzül etmeden sadece Allah'a kavuşmayı arzularlar:

Seni seven kişiye ne hâcet hûr u kusûr

Seni sevmeyen câna tamudur cümle makâm (202/4)

Hz. Mûsâ, Tûr Dağı'nda Allah'ın tecellisine mazhar olan peygamberdir. Tasavvufî manada Hz. Mûsâ ve Tûr'dan maksat, sâlik ve gönüldür. Bu açıdan bakıldığında şair, kendisini Hz. Mûsâ'ya benzetince (teşbîh), gönlünü de Tûr Dağı'yla ilişskilendirmiş olmaktadır (açık istiâre). Böylece Yûnus Emre, hadîs-i kudsî olduğu ileri sürülen “Yere ve göğe siğmam, fakat mü’min kulumun kalbine siğarım.” sözünü hatırlatarak (telmîh), âşığın gönlünü Allah'ın isim ve sıfatlarının yansıdı̆̆ı bir ayna gibi düşünmüştür. Zaten şair, pek çok şiirinde, Hz. Mûsâ'nın dua mekânı olan Tûr'a mukabil kendi münâcât yeri olan gönlünden sıkça bahsetmektedir:

Şu benüm hâcet-gâhum Tûr Tagı oldı meger

Mûsî'leyin bu gönlüm hoş münâcât eyledi (364/3)

Allah Tûr Dağı'na tecelli edince Mûsâ Peygamber'in aklı başından gitmiş ve hayran bir vaziyette olduğu yere yığılıp kalmıştır. Şair, kendisinin de bu durumda olduğunu söylemiş, Allah'a kavuşarak kendinden geçtiğini dile getirmiştir:

Gör Mûsâ Tûr içinde bir tecellî neler kilur

Yir gök tolu tecellîür ya ben niçe sabr eyleyem (206/4)

\section{- Sekizinci Beyit}

Kalem çalınicak görgil haber böyle durur bilgil

Kâlû belâ kelecisin bunda haber viren benem

$$
\text { قالم بلا كلجسين بوركل خبر بويله درور بيلكل }
$$

Kelime Bilgisi (Söz Tabakası): 1. kalem çal-(1n-1cak) [A.is.+T.f.]: Yaz(11)mak. (tasvf.) Yarat(1l)mak; nûr-1 Muhammedî, nefs-i küllî. 2. gör-(gil) [T.f.]: Algılamak, hissetmek; anlamak, idrak etmek. 2. haber [A.is.]: Bir olay, bir olgu veya bir kişi hakkında edinilen bilgi. (tasvf.) Hakikat ilmi. 3. böyle durur [T.sf.+T.e.f.]: $\mathrm{Bu}$ şekildedir. 4. bil-(gil) [T.f.]: Bir şey hakkında bilgisi olmak. (tasvf.) Hakikat ilmine sahip olmak. 5. Kâlû belâ [A.cüm.]: "Evet” dediler (A’râf, 7/172). (tasvf.) Elest meclisi, 
Allah'la kul arasındaki sözleşme. 6. keleci-(si-n) [T.is.]: Sözleşme, anlaşma. 7. bunda [T.zm.]: Burada. (tasvf.) Dünya hayatı. 8. haber vir-(en) [A.is.+T.y.f.]: Bir şeyi bildirmek, bir şey hakkında bilgi vermek. 9. ben-(em) [T.zm.]: Türkçe teklik birinci şahıs zamiri.

Çeviri (Anlatı Tabakası): 1. Beytin düzyazıya çevrilişi: Kalem çalınıcak görgil, haber böyle durur bilgil. Kâlû belâ kelecisin bunda haber viren benem. 2. Beytin diliçi çevirisi: (Ey insan!) Allah'ın takdir ettiğinin gerçekleşeceğini düşün ve anla. (Allah'ın bildirdiği gerçek) haber bu şekildedir. Elest meclisinde yapılan sözleşmeyi (insanlığa) haber veren (yani bildiren/hatırlatan) benim.

Dil ve Anlatım (Üslup Tabakası): Beyitte iki kelime (haber, kâlû belâ ) dışındaki bütün kelimeler Türkçe söz varlığına aittir. Şair, beyti "görgil, bilgil" kelimeleriyle yaptığı "emretme" ve "istekte bulunma" cümleleriyle kurgulamış ve bu cümleler de "hatırlatma" ve "ikazda bulunma" amacını takip etmiştir. Beyitteki en önemli ifade biçiminin ise "tevriye" ve "İktibâs" olduğu görülür. Yûnus Emre, şathiyeci ve vahdet-i vücûdcu anlatım tarzını bu beyitte de açıkça göstermiştir.

Şiirsel Anlam (Şerh Tabakası): Yûnus Emre bu beyti, vahdet-i vücûd nazariyesinin bir sonucu olan abd ile mabûdun birlik hâlini yansıtacak şekilde kaleme almıştır. Çünkü Allah'ın haberlerini kula iletmekle görevli şahıslar peygamberlerdir. Ancak, şair bu görevin dünya hayatında kendisine verildiğini söyleyerek Allah'la arasında hiçbir varlığını bulunmadığını belirtmiştir:

Benem Hakk'un kudret eli benem belî 'ş̧k bülbüli

Söyleyüp her türlü dili halka haber veren benem (193/11)

Beyitteki "kalem çalınmak" deyimi, iki anlamı da ifadeye uygun gelecek şekilde kullanılmıştır (tevriye). Bilindiği üzere kalem kelimesinin ilk anlamı yazı yazmaya yarayan âlettir ve Türk-İslâm kültüründe şerî anlamdaki "kader”le "yazmak" kelimesi arasında "alın yazgısı" biçiminde bir ilişki söz konusudur. İşte Yûnus Emre "kalem çalınmak" deyimini şiirlerinde daha çok "kaza-kader" düşüncesini ortaya koymak amacıyla kullanmış, bu deyimle Cenâb-1 Hakk'ın insan ve dünya için ezelde takdir ettiği 
her şeyin bir gün gelip gerçekleşeceği hakikatini dile getirmek istemiştir. Ona göre Allah insanın kaderini ezel bezminde "levh" üzerine yazmıştır. Ezelde ne yazılmışsa insanın başına o gelecektir:

Yûnus imdi gam yime n'idem ne klam dime

Gelür kişi başına ezelden ne yazıla (335/20)

Şair bu deyimle ikinci olarak tasavvufî bir 1stılah olan "Nûr-1 Muhammedî/Nefsi Küllî”yi anlatmıştır. Buna göre: Allah ilk tecellisiyle Muhammedî nuru yaratmış, daha sonra da ondan taşan tecellilerle diğer mahlukatı vücuda getirmiş ve getirmeye devam etmektedir. Şu hâlde varlıklar, kudret kaleminin yazdığı şekilde, yani Allah'ın takdir ettiği biçimde Muhammedî nurun bir zuhurudur. $\mathrm{Bu}$ zuhur, tenezzül ve terakki makamlarından geçerek tekrar geldiği âleme karışacak; varlıklar içinde en güzel kıvamda yaratılan insan da bu süflî âlemden kurtulup tekrar aslî vatanına, yani "mutlak varlığa” dönecektir. Yûnus Emre'nin ifadesiyle kalem çalınarak takdir edilen yazılacak, yani Cenâb-1 Hakk'ın “Onlar Allah'tan geldiler ve yine Allah'a dönecekler (Bakara, 2/156)." diyerek haber verdiği dönüş (teferrüc) hakikati zâhir olacaktır:

Ne oda yanam dagılam ne dâra çıkam bagıram

Iş̧üm bitince yüriyem teferrüce geldim ahî (370/9)

Şairin A'râf Sûresi 172. ayetten alıntı yaptığı (iktibâs) "kâlû belâ (Evet dediler.)" ibaresi, elest bezminde ruhların Allah'a kulluk için verdikleri sözü anlatır. Yûnus Emre, dünyada kulluğunu yerine getiren, elest şuuru içinde yaşayan ve ahdine vefa gösteren kâmil bir mümin olarak, kendisini bu ezelî sözleşmeyi insalara bildirmek ve yeri geldikçe de bu ahdi onlara hatırlatmakla vazifeli görmektedir:

Va'de kildik ol dostıla biz bu cihâna gelmeden

Pes ne kadar eglenevüz ol va'demüz yitse gerek (135/2)

Şair, beyitteki "haber" kelimesiyle de "aşk"1 kasteder. Çünkü ona göre "Kâlû belâ" sözü bir "aşk haberi”nden ibarettir ve bu haberi de ancak “dost yüzünü görenler" verebilmektedirler: 
Evvel ezel bezminde kim dost yüzin gördiyse

Anun cânıdur 'âşık sor andan 'ş̧k haberin (254/4)

\section{- Dokuzuncu Beyit}

Delü oldum adum Yûnus 'ışk oldı bana kulavuz

Hazret'e degin yalunuz yüz süriye varan benem

$$
\begin{aligned}
& \text { دلو اولدم آدم يونس عشق اولاى بكُا قو لاوز } \\
& \text { حضرته دكن يالوكّز يوز سورييه وار ارنان بنم }
\end{aligned}
$$

Kelime Bilgisi (Söz Tabakası): 1. delü ol-(du-m) [T.is.+T.y.f.]: Aklî dengesi bozulmak; çok sevmek, çok istemek. (tasvf.) Âşık olmak. 2. ad-(um) [T.is.]: Varlıkları karş1layan kelime, isim; şöhret, nam, şan. 3. Yûnus [A.öz.is.]: Yûnus Emre. 4. '1şk [A.is.]: Bir şeye karşı aşırı düşkünlük. (tasvf.) Allah sevgisi. 5. kulavuz ol-(d1) [T.is.+T.y.f.]: Yol gösterici olmak, delil olmak. (tasvf.) Şeyhin müridine mürşitlik yapması. 6. ban-(a) [T.zm.]: Ben zamirinin yönelme hâli; benim için. 7. Hazret-(e) [A.is.]: Huzur, ilâhî dergâh. (tasvf.) Makam, mertebe, Hakk'1n huzuru. 8. degin [T.e.]: e kadar, -e dek. 8. yalunuz [T.zf.]: Tek başına; sadece. 9. yüz süri-(y-e) [T.is.+T.f.]: (Sevgi veya sayg1 ifadesi olarak) huzurunda yere kapanmak; zorluklara katlanmak. 10. var-(an) [T.f.]: Ulaşmak, erişmek, vasıl olmak. (tasv.) Hakk'a ermek, kemale ermek; seyr ü sülûku tamamlamak. 11. ben-(em) [T.zm.]: Türkçe teklik birinci şahıs zamiri.

Çeviri (Anlatı Tabakası): 1. Beytin düzyazıya çevrilişi: Delü oldum, adum Yûnus. 'Işk oldı bana kulavuz. Hazret'e degin yalunuz (ve) yüz süriye(rek) varan benem 2. Beytin diliçi çevirisi: (Benim) adım Yûnus(tur). (Ben) deli oldum (yani, Allah sevgisiyle aklî melekemi kaybettim) (fakat) aşk bana yol gösterdi (ve benim mürşidim oldu). (Böylece) tek başıma (yani, aşktan başka hiçbir şeye ihtiyaç hissetmeden) (ve) büyük bir hürmetle (ya da çeşitli sıkıntılara katlanarak) Hazret-i Allah'a vasıl olan (ve bu hâl üzere seyr ü sülûkunu tamamlayan) benim.

Dil ve Anlatım (Üslup Tabakası): $\mathrm{Bu}$ beyit hem şekil hem de içerik bakımından gazelin makta' beyti olma özelliğini açıkça gösterir. Beyitteki “aşk” ve "Hazret" kelimeleri hariç bütün kelimeler Türkçedir ve bu yönüyle şair gazelini başladığı şekliyle sade ve arı bir Türkçeyle bitirmiştir. Gazelin birinci beytinde (matla') "aşk"1 bulan kişinin kendisi olduğunu söyleyen Yûnus Emre, bu beyitte ise "aşk" ile hedefine vardığından bahsetmiş, böylece gazelin başıyla sonu arasında kuvvetli bir 
anlamsal ilişki kurmuştur (yek-âhenk gazel). Şair, diğer şiirlerinde olduğu gibi bu gazelinin son beytinde de mahlas olarak "Yûnus" kelimesini kullanmış, böylece hem dîvân şiirinde hem de dinî-tasavvufî̀ şiirde pek çok şair tarafindan benimsenen bu geleneğe tabi olmuştur. Beyitteki en önemli üslup özelliği ise, şairin “delü, ad, kulavuz ve yüz sürmek" kelimelerinin yan ve terim anlamlarıyla (tevriye) oluşturduğu mana derinliğ $i$ ve zenginliğidir.

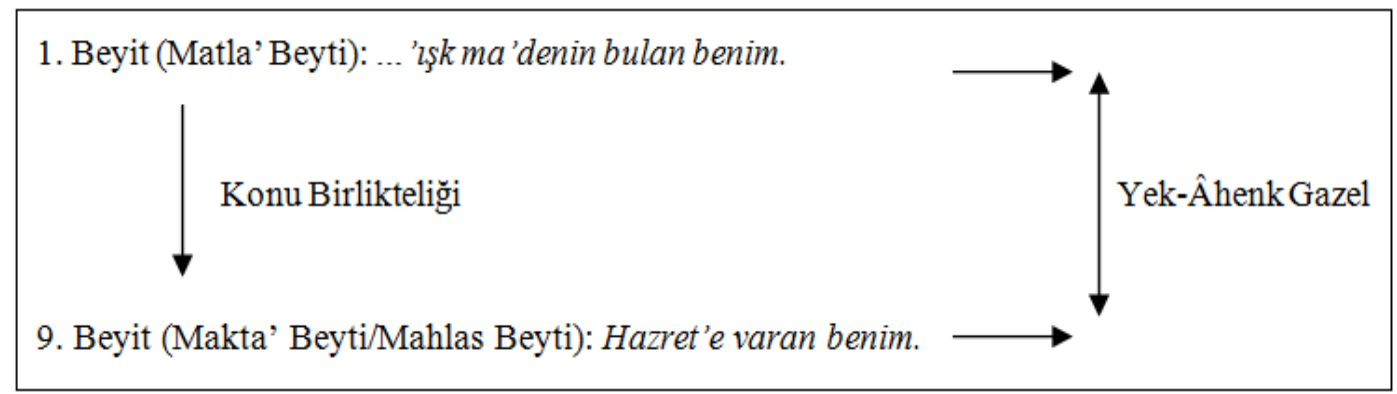

Şiirsel Anlam (Şerh Tabakası): Tasavvufî şiirde âşıla ilgili en belirgin özelliklerden birisi de onun bir “deli/delü”ye benzetilmesidir. Yûnus Emre de gazelinin bu son beytine kendisini bir deliye benzeterek başlar (teşbîh). Bilindiği gibi insanın uğruna her şeyi göze alabileceği hislerinin başında sevgi/aşk gelir. Âşık, sevgiliye duyduğu muhabbetle her türlü çılgınlıkta bulunabilir. O, aşkın verdiği hâller karşısında hayran ve mest kalmış, hatta aklını yitirmiştir. Aslında onun bu deliliği, ilâhî tecelliler ile benliğini kaybedip müşâhede makamına ulaşmasıyla ilgilidir.

Hâl böyle olunca sıradan insanlar arasında yadırganan delilik, sûfî âş1k için varılmak istenen gerçek hedef olarak düşünülmüştür. Nitekim, Yûnus Emre beyitteki "ad" kelimesinin "şan ve şöhret” biçimindeki yan anlamıyla (tevriye) bu manayı da sezdirmiş, Allah'a beslediği aşkın ve bu aşk neticesinde ulaştığı delilik hâlinin dillere destan olan şöhretinin asıl sebebi olduğunu hissettirmiştir:

\section{Iy 'ışk delüsi olan ne kaldın perâkende \\ Ol senü deli kılan yeni sendedür sende (328/1)}

Tasavvuf muhitlerinde kılavuz şeyhtir. Kılavuz kelimesinin ayrıca "delil” anlamı da vardır. Şaire göre aşk, onun hem kılavuzu hem de insân-1 kâmil mertebesine ulaştığının bir ispatıdır (tevriye). Yûnus Emre, kendisine rehberlik edenin yalnızca aşk 
olduğunu söyleyerek fenâfillâh mertebesine ulaştığını, böylece Allah'la arasında hiçbir varlığın kalmadığını dile getirmiştir.

Malum olduğu üzere, kılavuz, varılmak istenen maddî veya manevî hedefi kendi aklıyla kestiremeyen insanların aldığı destektir. Ancak beyitte bir zıtlık söz konudur. Çünkü Yûnus Emre'ye göre aşk hem deliliğin, yani bir kılavuza ihtiyaç duyma hâlinin sebebidir hem de bizatihi kılavuzun kendisi, yani delilikten kurtulmanın reçetesidir. O hâlde şaire göre, dert (delilik) de derman (kılavuz) da "aşk"tır:

Yûnus'dur 'ışk âvâresi bî-çâreler bîçâresi

Sendedür derdüm çâresi dermânum soram yüriyem (213/6)

Beyitteki "varan” kelimesiyle kastedilen Hakk'a “vuslat”tır. Ancak, şairin bu 1stılahı son beyitte kullanması şüphesiz ki tesadüfî̀ değildir. Gazel bu beyitle kemale erdiği gibi, şair de aşk sayesinde yüz sürüyerek, yani bir an bile Allah'ın huzurunda olduğunu unutmayarak ya da çeşitli sıkıntılara göğüs gerekerek (tevriye) seyr ü sülûkunu tamamlamış ve Hazret-i Allah'a vâsıl olmuştur:

'Âşık mıyıdı Yûnus vuslat bulaydı bugün
'Âşı karâr mı ider yarınki va'deyile (338/9)

\section{Sonuç}

Son dönemlerde, Tanzimat sonrası Türk edebiyatı metinleri üzerinde olduğu kadar klâsik dönem dinî-edebî metinler üzerinde de modern inceleme yöntemlerinin sıkça kullanıldığ1 görülmektedir. Şüphesiz ki edebiyatımızda metin tahlil çalışmaları "şerh" geleneği bağlamında oldukça eskiye dayanmakta ve yeni yöntemlerde gördüğümüz pek çok temel prensibe bu gelenekte rastlanmaktadır.

Geçmiş usüllerle hâlihazırdaki yöntemler arasındaki bu sıkı irtibat, "interdisipliner" çalışmaları daha önemli hâle getirmekte; kâsik metinlerin anlaşılması, yorumlanması ve değerlendirilmesinde "çoğulcu” yaklaşımın önemini iyice artırmaktadır. Çünkü hiçbir edebî eser yazıldığı dönemin "tarihî, siyasî, ekonomik ve kültürel" özelliklerinden azade değildir ve her edebî metin muhakkak ki sanatkârının 
şahsî ve ruhî portresi hakkında bazı ipuçlarına sahiptir. O hâlde dinî-edebî metinlerin doğru anlaşılabilmesi bu metinlere "toplum-şair-metin-okur" bağlamında yaklaşmakla mümkündür.

Ancak, şurası asla unutulmamalıdır ki hiçbir eser kendi dışındaki ilimlere ve disiplinlere fayda sağlamak için üretilmemiştir. Bundan dolayı metin tahlillerinde yapılması gereken, metnin yazılış amacı bakımından önceliğinin ne olduğunu belirleyerek bu amaca uygun olan tahlil yöntem(ler)ini tespit etmek, daha sonra da metnin diğer alanlarla olan ilişkisi üzerinde durarak yapılan tahlili detaylandırmak ve desteklemektir. Örneğin incelemeye çalıștığımız Yûnus Emre'nin gazeli, tasavvufî duygu ve düşünce merkeze alınarak mı yazılmış, estetik gayenin ön planda tutulduğu edebî bir eser olarak mı vücuda getirilmiş yoksa her iki kaygının da eşit düzeyde önemsenmesiyle mi kaleme alınmıştır? Şüphesiz ki bu sorunun cevabı bizzat metnin kendisindedir. Öyleyse, metin tahlillerinde, bütün tali unsurlar ve disiplinlerden yararlanmakla birlikte esas alınması gereken temel kriter, metnin kendisini tetkik etmeye çalışmaktır.

İşte, üzerinde durduğumuz gazel bu düşünce çerçevesinde bir incelemeye tabi tutulmuştur. Esasen yapmak istediğimiz şey, herkes tarafindan kabul edilecek bir inceleme değil, önceden sahip olduğumuz ve sonrasında da edinmeye gayret sarfettiğimiz birtakım bilgi ve birikimlerle dinî-tasavvufî edebiyatımızın en müstesna şahsiyetlerinden biri olan Yûnus Emre'nin bu gazelinde bize ne demek istediğini "doğru” olarak kavramaya çalışmaktır.

Bu çalışmayla elde ettiğimiz sonuçları da şöylece sıralamamız mümkündür:

1. Bu gazel Yûnus Emre Dîvânı'ndaki dokuz adet "benem” redifli gazelden biri(nci)sidir. Şair bu gazeli “devr/teferrüc” hakikatini ve "vahdet-i vücûd” düşüncesini anlattığg şiirlerinden biri olarak kaleme almış; gazelin temasını "aşk", konusunu ise aşkın kılavuzluğunda yaptığı kendi “seyr ü sülûk”u olarak belirlemiştir.

2. Gazel dokuz beyitten oluşmaktadır. Bu beyitlerin birbirleriyle olan şekilsel irtibatı klâsik nazım şekillerinden olan gazel ve kasîde formatına (aa, ba, ca ...) 
uygunluk arz eder. Şair, beyitlerde kullandığı dilin şiirsellik işlevine paralel olarak dinîtasavvufî̀ bazı sembollere ve edebî sanatlara yer verse de bunlar kasîdenin geneline hâkim olan "anlaşılma” amacına gölge düşürecek düzeyde değildir. Nitekim şair, tercih ettiği kelimelerin çoğunu Türkçe söz varlığından seçerek beyitlerini bu amacına uygun olarak açık ve sade bir dille kaleme almış; hatta bazı dinî-tasavvufi terimlerin Türkçe karşılıklarını kullanarak bu hassasiyetini kasîdenin tamamında sürdürmüştür.

3. Kaynaklarda geçtiği üzere Yûnus Emre, vahdet-i vücûd nazariyesini halkın seviyesine indirebilen ilk Anadolulu şairdir. O, bu gazelinde kendi seyr ü sülûkunun en önemli mertebesi olan "fenâfillâh”a ulaştığını kullandığı "şatahat” üslubu ile göstermiş, bu üslubun en belirgin özelliği olan "yaratıcının diliyle konuşma” tarzını birkaç beyitte yinelemiştir.

4. Gazel, baştan sona tek bir konuyu anlatması yönüyle "yek-âhenk gazel” niteliğindedir. Şair, birinci beyitte, âşıkların en genel vasfı kabul edilen "âş̧ılıkta zirvede olma" iddiasını dile getirmiş; paha biçilemez bir madene benzettiği "aşk" rehberliğinde Allah'a vâsıl olduğunu da son beyitte belirtmiştir. Aradaki beyitlerde ise şairin gerçekleştirdiği aşk yolculuğunun köşe taşlarından bahsedilmiş, bu yönüyle bir nevi şairin "vuslat” serüveni anlatılmıştır:

Ona göre, Allah’a iman "bilmek-görmek-göstermek” demektir, yani imanını aşk ile gösteremeyenlerin bilmek ve görmek davaları geçersizdir. Şair, aşkın elest bezminde takdir edildiğini düşünür. Mahşer günü Allah’a verilen aşk sözünün hesabı sorulacaktır ve insana verilen en doğru haber de budur. Aşk, bütün kâinatı kaplamıştır. Sâlike düşen görev, bir su kuşu gibi aşk denizine dalmak ve bu denizin içindeki cevheri çıkarabilmektir. Yûnus Emre'nin hedefi “insân-1 kâmil” mertebesine ulaşabilmektir. Esasen bu, insanlığın da yaratılış gayesidir. Şüphesiz ki sûfînin bu amaca tek başına varması mümkün değildir. Onun mürşidi bağlandığı şeyhi ve Hz. Peygamber'idir. Ancak, "fenâfi'ş-şeyh" ve "fenâfi'r-resûl” makamlarını kateden bir muvahhid, yolculuğunun geri kalan kısmında sadece “aşk”1 rehber tutarak Hazret-i Allah'a kavuşabilecektir. 
5. Yûnus Emre, gazelinde kendi psikolojik portresini çizerken hem yaşadığ toplumun en temel dinamiklerinden biri olan “tasavvuf” düşünce sistemi hakkında özet bilgiler vermiş hem de metin içinde bıraktığı boşluklarla okura yorum imkânı tanımıştır. Bu yönüyle gazel, “interdisipliner” ve "çoğulcu” yaklaşımlarla anlaşılabilecek bir dinîedebî metin görüntüsüne sahiptir. 


\section{KAYNAKÇA} Yayınları.

AKAR, Metin (1994). "Metin Şerhi Meselesi”, Su Kasidesi Şerhi, Ankara: TDV

AKKUŞ, Metin (1992). "Metin Şerhi Geleneği Tarlan Mektebinden Haluk İpekten'e", Yedi İklim, 32: 67-78.

AKTAŞ, Şerif (2009). Şiir Tahlili (Teori-Uygulama), Ankara: Akçağ Yayınları. Yayınlar1.

AYTAÇ, Gürsel (2013). Karşılaştırmalı Edebiyat Bilimi, İstanbul: Say

BAYRAM, Yavuz (2016). "Şerhten Çözümlemeye Tahlilden İncelemeye Gazel”, Eski Türk Edebiyatı Çallş̧maları XI Gazelden Gazele: Dünün Şiirine Bugünden Bakışlar (Haz. Hatice Aynur vd.). ss. 288-344, İstanbul: Klasik Yayınları.

BİLKAN, Ali Fuat (2006). Osmanl Şiirine Modern Yaklaşımlar, İstanbul: LM Yayınlar1.

CANIM, Rıdvan (1996). "Metin Şerhi Geleneğimiz Çerçevesinde Tarlan ve İpekten'in Kaleminden Fuzuli'nin 'Sana' Redifli Gazeli’, Fuzuli Kitabl: 500. Yllinda Fuzuli Sempozyumu Bildiriler, (Haz. Beşir Ayvazoğlu). ss. 129-140, İstanbul: Büyük Şehir Belediyesi Kültür İşleri Dairesi Başkanlığı Yayınları. Yayınları.

CENGIZ, Metin (2006). Şiir, Dil, Şiir Dili, Şiirsel Anlam, İstanbul: Şiirden

CEYLAN, Ömür (2007). Tasavvufi Şiir Şerhleri, İstanbul: Kapı Yayınları.

ÇAĞBAYIR, Yaşar (2007). Ötüken Türkçe Sözlük, İstanbul: Ötüken Yayınları.

ÇELEBİŎLU, Âmil (1998). "Yûnus'un Şiirleriyle İlgili Şerhler", Eski Türk Edebiyatı Araştırmaları, ss. 547-552, İstanbul: MEB Yayınları.

ÇETişLİ, İsmail (2014). Edebiyat Sanatı ve Bilimi, Ankara: Akçağ Yayınları.

ÇEVIRME, Hülya (2001). "Yunus Emre'nin Bir Şiirinin Göstergebilim Açısından İncelenmesi”, A.Ü. Türkiyat Araştırmaları Enstitüsü Dergisi, 17: 75-80.

DİLÇín, Cem (2000). Örneklerle Türk Şiir Bilgisi, Ankara: TDK Yayınları.

DİLÇİN, Cem (2003). "Cumhuriyet"in 80. Yılında Divan Şiiri Üzerine Düşünceler", Türkoloji Dergisi, 16/2: 1-21.

DOĞAN, Aksan (2013). Şiir Dili ve Türk Şiir Dili, Ankara: Bilgi Yayınevi.

DOĞAN, Muhammed Nur (2002). "Metin Şerhi Üzerine", Eski Şiirin Bahçesinde, ss. 11-25, İstanbul: Ötüken Yayınları.

EMRE, M. Efdal (2015). Yûnus Emre Dîvânı ve Şerhi, İstanbul: Eserkitap Yayınlar1. 
GÜLEÇ, İsmail (2010). "Klasik Türk Edebiyatı Metinleri Nasıl Şerh Edilmeli?”, I.Ü. Edebiyat Fakültesi Türk Dili ve Edebiyatı Dergisi, 42: 83-112.

İPEKTEN, Haluk (1999). Eski Türk Edebiyatı Nazım Şekilleri ve Aruz, İstanbul: Dergâh Yayınları.

KAPLAN, Mehmet (1979). Hikâye Tahlilleri, İstanbul: Dergâh Yayınları.

KOLCU, Ali İhsan (2011). Edebiyat Kuramlarl (Tanım-Tenkit-Tahlil), Erzurum: Salkımsöğ̈̈t Yayınları.

KORTANTAMER, Tunca (1994). "Teori Zemininde Metin Şerhi Meselesi”, EÜEF Türk Dili ve Edebiyatı Araştırmaları Dergisi, 8: 1-10.

KÖPRÜLÜ, Mehmet Fuad (2014). Türk Edebiyatında İlk Mutasavviflar, İstanbul: Alfa Yayınları.

MENGİ, Mine (2000). "Metin Şerhi, Tahlili ve Tenkidi Üzerine”, Divan Şiiri Yazıları, ss. 72-80, Ankara: Akçă̆ Yayınları.

MENGİ, Mine (2007). "Metin İncelemesi Aşamaları, Terimleri ve Bunlardan Biri: Metin Tahlili", Turkish Studies, 2/3: 407-417. Yayınlar1.

MORAN, Berna (2005). Edebiyat Kuramları ve Eleştiri, İstanbul: İletişim

OKAY, Orhan (1990). "Eski Şiirimize Yaklaşmak", Sanat ve Edebiyat Yazıları, ss. 82-87, İstanbul: Ötüken Yayınları.

ÖZER, Nilay (2005). “Ahmet Atilla Şentürk'le Divan Şiiri Üzerine”, Yasakmeyve Dergisi, 12: 50-51.

PARLATIR, İsmail (2006). Osmanlı Türkçesi Sözlüğü, Ankara: Yarg1 Yayınları.

PEKOLCAY, Necla ve Emine SEVIM (1991). Yunus Emre Şerhleri, Ankara: Kültür Bakanlığı Yayınları.

PEKOLCAY, Necla (1992). "Metin Şerhi Hakkında", I. Eski Türk Edebiyatı Kollogyumu, 17-18 Ocak, Ankara: İlesam Yayınları.

SARAÇ, Yekta (1999). "Divan Tahlilleri Üzerine", İlmi Araştırmalar Dil, Edebiyat, Tarih Incelemeleri, 8: 209-219.

SARAÇ, M. A. Yekta (2011). Klâsik Edebiyat Bilgisi Belâgat, İstanbul: Gökkubbe Yayınları.

SARAÇ, M. A. Yekta (2012). Klâsik Edebiyat Bilgisi Biçim-Ölçü-Kafiye, İstanbul: Gökkubbe Yayınları.

TARLAN, Ali Nihat Tarlan (1981). "Metinler Şerhine Dair", Edebiyat Meseleleri, ss. 191-204, İstanbul: Ötüken Yayınları.

TATCI, Mustafa (2008a). Yûnus Emre Külliyâtı I/Yûnus Emre Divânı-Tenkitli Metin, İstanbul: H Yayınları. 
TATCI, Mustafa (2008b). Yûnus Emre Külliyâtı I/Yûnus Emre Divânı-Inceleme, İstanbul: H Yayınları.

TATCI, Mustafa (2008c). Yûnus Emre Külliyâtı V/Yûnus Emre Şerhleri, İstanbul: H Yayınları.

TATCI, Mustafa (1997). Edebiyattan İçeri, Ankara: Akçağ Yayınları.

TOPRAK, Metin (2003). Hermeneutik (Yorum Bilgisi) ve Edebiyat, İstanbul: Bulut Yayınları.

ULUDAĞ, Süleyman (2005). Tasavvuf Terimleri Sözlüğ̈̈, İstanbul: Kabalc1 Yayınlar1.

YAKIT, İsmail (2002). Çıktım Erik Dalına-Yunus Emre'de Sembolizm, Ankara: KB Yayınları.

YAVUZ, Hilmi (2005). Edebiyat ve Sanat Üzerine Yazllar, İstanbul: YKY Yayınlar1.

YENITERZİ, Emine (1999). "Metin Şerhi ile İlgili Görüşler”, SÜ Türkiyat Araştırmaları Enstitüsü Türkiyat Araştırmaları Dergisi, 5: 59-68. 